\title{
SI PROPONE CIÒ CHE SI DEVE DELIBERARE CIRCA SOCRATE
}

La difesa di Socrate per alcuni giorni nella publica redunanza con non mediocre attentione fu d'Accademici ascoltata, e non poco di comottione nella mente de giudici cagionò, distrahendosi in diversi pareri i loro animi: molti non solamente inclinavano all'assolutione, ma di più stimavano ragionevole decretare a Socrate alcuna rimostranza di

Alcuni vogliono assolvere Socrate e rimunerarlo.

Almeone propone che si condanni Socrate. honore, comparandolo ad Ercole che scacciò dal mondo sensibile le monstruosità, onde questo dal mentale le detruse. Proponevano anco di più, che conforme il socratico parere si dovesse ordinare che nelle materie mere humane si dovesse sospendere per l'avenire il giuditio, e retinirlo in giusto equilibrio tra l'affermare e negare, evitando perciò li contumaci scoglii che sì spesso inducono all'intelletto naufragio, ma che di più anco, con felice successo dell'ingegni, l'eloquenza esercitio proprio dell'homo al sommo si condurebbe, havendo amplissimo loco di spatiare, non essendo ristretta, e contratta ad alcuno terminato e limitato dogma. [315] Et insomma concludevano che a risanare et appianare l'enfiature e tumori del nostro animo, riusciva tal sospensione di giuditio, ottimo rimedio.

Ma Almeone di setta pitagorica celebre professore di dogmi, gagliardamente invehì contro quelli che attentavano di Socrate l'assolutione, reclamando che tale giuditio traboccava dalli limiti della clemenza, e che ad ogni modo sostenere si dovesse la dignità dell'humane dottrine, a quali si appogia il decoro del nostro genere, aggiungendo che tal affare era molto considerabile, e d'importante rilievo, per le cattive consequenze che dalla indemnità di Socrate ne sarebbero successe, e che ad un colpo si dannava e demoliva tutto l'universo intellettuale non meno amplo e difuso, che il reale, e che insieme si harebbe abolita la veneranda memoria di tanti celebratissimi homini, che hanno insudato, per lasciare alla posterità venerandi monumenti della loro dottrina, e che Socrate si mostrò del suo proprio genere più nemico, che l'istesso Timone, havendo tentato con lo screditare le dottrine, indurre l'homini nel rolo de bruti, diversificando quelle, l'uni dalli altri.

Ma Platone calcando una mediocre strada in tal maniera apunto favellò: 


\section{DRAFT RESOLUTION CONCERNING SOCRATES}

Socrates's defence was very carefully heard in the presence of the Academicians in the public assembly over a few days, and it produced no little disquiet in the minds of the judges, whose minds turned to different opinions: many not only inclined to his absolution, but they furthermore considered it reasonable to decree that Socrates should be honoured by comparing him with Hercules, who cast monstrosities out from the sensible world, while he [i.e., Socrates] destroyed them in the mental one. They further proposed that in accordance with Socratic opinion, it should be ordered that judgment on mere human matters should be suspended for the future and the correct balance between affirmation and denial should be retained. Therefore, this would avoid the obstinate rocks which so often induced shipwrecks in the intellect, and moreover, it would lead eloquence, as the proper exercise of human beings, to achieve its peak, leading to the happy success of the wits. It would thus have a wide space in which to ramble, being unrestricted and not constricted into any enclosed or limited dogma. [315] And, in summary, they concluded that this suspension of judgment was a successful remedy to heal and smooth away the blisters and swellings of our minds.

Yet Alcmaeon, a well-known professor of dogmata from the Pythagorean sect, strongly reacted to those who attempted to absolve Socrates by claiming that this judgment surpassed the limit of clemency. [He claimed that] the dignity of human doctrines, on which the decorum of humankind relies, had to be defended. He continued that this issue was most considerable and of relevant importance because of the negative consequences which could follow from Socrates's indemnity: namely, that the entire intellectual universe - which is no less spacious and extensive than the real one - would be damned and demolished at a stroke; furthermore, that the venerated memory of many lauded men who had suffered in order to leave the revered records of their doctrines to posterity would be abolished. Moreover, that Socrates had shown himself to be a greater enemy of humankind than Timon himself, because he had attempted to induce human beings to assign themselves the role of brutes by discrediting doctrines, which differentiate the latter from the former.

Yet Plato, pursuing a middle path, indeed spoke in this way:
Some want Socrates to be absolved.

Alcmaeon suggests sentencing Socrates. 
Platone propone che non si debba determinare cosa alcuna hora circa Socrate.
"Qual sia stata la riverenza che io verso Socrate, amico e precettore mio, habbia per il passato professato, evidente attestatione ne rendono li miei scritti havendolo sempre con filosofico decoro introdotto, e con la protettione del suo nome alla ventura posterità raccomandatili. Et anco credo, che non vi sia alcuno in questa nobilissima assemblea, che li sia occulto la stima in che tengo l'humane dottrine, havendo io per apprenderle, consumato non meno buona parte di patrimoniali haveri, che gran spatio del tempo di mia vita. Per il che privo di ogni partiale affetto, son per pronontiare il mio parere, circa il modo che tenire si deve nel giudicare Socrate.

Stimo dunque ragionevole, che l'istesso instituto ch'egli tiene nel giudicare le cose che se li apparano, dobbiamo ancor noi verso di lui praticare. Ratiene egli il suo assenso, e noi sospendaremo circa esso il nostro giuditio, [316] né ad alcuna decisione peremptoria pro nunc diveniamo arrestando la sentenza difinitiva, insin tanto che ci emerga alcuna più evidente instanza che ci conduca ad assolverlo over dannarlo, in modo che hora rimanga libero a quelli che sinistramente di esso intendono il dire, che essendo stato citato, et intimate le difese, e non essendo assoluto, che non affatto purgasse la sua colpa. Et ad altri di lui fautori, il pretendere che havendo noi esercitato verso di esso il proprio suo stile, di sospendere il giuditio, habbiamo il di lui instituto approbato, et accennata la sua assolutione.

Da tale nostra deliberatione sortisce non solamente questo avanzo, che né Socrate affatto discapita della sua stima, né le dottrine rimangono discreditate, ma di più altro profitto ne seguirà, ché l'homini per l'avenire diveniranno alquanto più circonspetti, e rattenuti nel pronontiare con immoderata pervicacia, e come irrefragabili i loro dogmi, né così fretolosamente come solevano ad ogni vana fantasma il loro assenso apprestaranno, rappresentandoli che Socrate del suo proprio sapere riuscì tanto dubbioso e titubante, né di ciò fu dannato né schernito".

$\mathrm{Fu}$ approvata et applaudita la proposta di Platone, e pro tunc lasciato l'affare indeciso. Dal che avenne ch'essendo stata l'accusa dall'Accademia accetata e non ispedita, la fama di Socrate diversamente sortì: al volgo delli homini apparì alquanto sospetta, non essendo seguita l'assolutione, ma alcuni de sapienti continuarno nel primiero buono concetto di stima che di esso già tenivano. 
"My writings give evident proof of the reverence in which I used to hold Socrates, a friend and preceptor of mine, since I would always speak about him with philosophical decorum and I have entrusted them [i.e., my writings] to future posterity under the protection of his name. Nevertheless, I believe that there is no one in this most noble assembly who does not know the esteem in which I [also] hold human doctrines. Indeed, I have consumed not only a substantial part of my patrimony, but also a considerable portion of my lifetime in apprehending them. Therefore, I am wholeheartedly going to utter my opinion concerning the way in which Socrates must be judged.

"I consider then that it is reasonable that we should follow the same rule regarding him that he adopts in judging the things that appear to him: namely that just as he withholds his assent, so will we suspend our judgment concerning him. [316] And we will not reach any peremptory decision thus far by preventing a final sentence in this way for as long as any more evident instance that could lead us to absolve or condemn him may emerge. In this way, he will be free of those who would maliciously say about him that although they sued him, ordering him to defend himself, and he was not absolved, nevertheless, he was not paying for his fault. Likewise, [he will be free] of others who are his supporters, who would suppose that since we had adopted his own style towards him - namely the suspension of judgment - then we had approved his rule and hinted at his absolution.

"From our decision, there will emerge not only the following advantage namely that Socrates's reputation will not be damaged and his doctrine will not be discredited - but also the further benefit: that people will become more circumspect in the future. Indeed, they will restrain themselves from pronouncing their dogmata with immoderate obstinacy as though they were irrefutable. Furthermore, they will not give their assent to vain phantasms as hurriedly as they used to, for they will have in their minds that Socrates, who was so doubtful and hesitant concerning his own knowledge, was not condemned or mocked because of this."

Plato's proposal was applauded and approved, and for that time, they did not make any decision concerning the issue. Hence, it happened that since the Academy had accepted the charge [of Socrates] but had not acquitted him, Socrates's fame spread in a different way: it appeared very suspicious to the common people, since he had not been absolved, while some of the wise men continued to hold him in the same high esteem as before.
Plato suggests that nothing must be defined about Socrates now. 


\section{Notes}

1 Luzzatto may have combined two different verses together in quoting this biblical passage. The first is taken from Ecclesiastes 9:16, "Then said I: “Wisdom is better than strength [...]” (ואמרתי אני טובה) חכמה מגבורה (ח), which is rendered as dicebam ego meliorem esse sapientiam fortitudine in the Clementine Vulgate. The second is Ecclesiastes 9:18, "Wisdom is better than weapons of war" (טובה חכמה מכלי קרב), which is rendered as melior est sapientia quam arma bellica in the Clementine Vulgate.

2 Luzzatto is referring to the war between the Venetians and the Ottoman Empire for the control of Crete from 1649 to 1669 . On 10 July 1651, which was the date his book was published, Tommaso and Lazzaro Mocenigo's fleets succeeded in defeating the Turks close to Paros.

3 This passage is relevant for its autobiographical information concerning Luzzatto's family's settlement in Venice. Luzzatto reports that his ancestors had already been living in Venice for two centuries, that is, since the second half of the fifteenth century. See also his Discourse, 3v.

4 On this simple offering of fine meal and baked goods, see Leviticus 2:1 and 6:14-23.

5 After his dedication, there is a list of errata, included in the text of the edition. Luzzatto introduces the list in the following way: "The author and printer: the correction of books is an extraordinarily skilful art. The person who took on the task of correcting this book had never practised this profession before. This is the reason for the infinite number of printing errors. Therefore, I implore the benign reader to amend every absurdity, such as the duplication of consonants or grammatical incongruities, and, in the event of any obscurities, to consider the following list of mistakes and to be kindly patient with human weakness."

6 The idea of passing through this world without leaving any traces, originally from Scripture, was a widely acknowledged negative concept in Luzzatto's time thanks to Dante's Divine Comedy, where, in canto 3 of Hell, he described the so-called neutrals (ignavi), namely those who had never taken sides in this world.

7 See Proverbs 30:18-19: “There are three things which are too wonderful for me, yea, four which I know not: The way of an eagle in the air; the way of a serpent upon a rock; the way of a ship in the

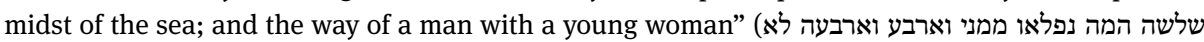

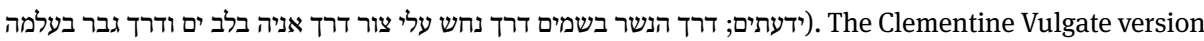
is: Tria sunt difficilia mihi et quartum penitus ignoro: viam aquilae in caelo, viam colubri super petram, viam navis in medio mari et viam viri in adulescentia.

8 Aesop, 70: the Lion and the Mouse. See the edition of Aesop's Fables which circulated widely in Venice in Luzzatto's time: Aesopus, Vita \& fabellae Aesopi cum interpretatione Latina ... Gabriae Fabellae tres \& quadraginta ... Phurnutus seu, ut alii, Curnutus De natura deorum. Palaephatus de non credendis historiis. Heraclides Ponticus de allegoriis apud Homerum. Ori Apollinis Niliacihieroglyphica. Collectio proverbiorum Tarrhaei, e Didymi, item eorum, quae apud Sudam aliosque habentur ... Ex Aphthonii exsercitamentis de Fabula ... De fabula ex imaginibus Philostrati ... Ex Hermogenis exercitamentis De fabula Prisciano interprete. Apologus Aesopi de Cassita apud Gellium (Venice: Aldum, 1505).

9 The vernacular alligatione (Latin alligatio) has been translated as "bonds."

10 See Plutarch, The E at Delphi F 384: "It seems that our beloved Apollo finds a remedy and a solution for the problems connected with our life by the oracular responses which he gives to those who consult him; but the problems connected with our power to reason it seems that he himself launches and propounds to him who is by nature inclined to the love of knowledge, thus creating in the soul a craving that leads onward to the truth, as is clear in many other ways, but particularly in the dedication of the E."

11 This personification of Reason and Authority seems to recall the discourse of Luigi Manzini (16041657), a former Benedictine monk and prelate in the Roman Curia who became a member of the Academy of the Incogniti and who was known for his commendation of nothingness. See Il Niente (Venice: Andrea Baba, 1634). Manzini defined philosophy as "hoary and rank" (canuta e rancida), as he aimed to free the mind from any dogmatic restriction. He accused dogmatic intellects of being betrayers of 
reason, as of one's own wife: "That libidinous wit, which repudiated its wife - which is Reason - and loves the concubine - which is Authority - must be condemned for adultery" (Condannasi per adultero quell'ingegno libidinoso, che ripudiando la sposa ch'è la Ragione, ama la concubine ch'è l'Autorità).

12 The gathering of information was a tool of the Inquisition. Luzzatto's "letterbox for secret denunciations" (recetacolo in the vernacular) recalls the "lions' mouths" (bocche de leon) established in Venice in order to collect denouncements before the trials. See Paolo Preto, Persona per hora secreta: Accusa e delazione nella Repubblica di Venezia (Milan: Saggiatore, 2003).

13 This is the first reference in the book to suspension of judgment (epochē), which is described by Sextus Empiricus as "standstill of the intellect, owing to which we neither reject nor posit anything." Sextus Empiricus, Outlines of Scepticism, ed. Julia Annas and Jonathan Barnes (Cambridge: Cambridge University Press, 2007), 1.10. This must be considered the load-bearing concept for the Sceptics, who are convinced that neither our perceptions nor our beliefs are to be trusted and that suspension of judgment is the proper attitude towards the world. Equipollence reigns in every inquiry in which Sceptics are engaged, demanding the suspension of judgment, which in their opinion restores peace of mind. See Julia Annas and Jonathan Barnes, The Modes of Scepticism (Cambridge: Cambridge University Press, 1985).

14 Hippias of Elis (fifth to fourth century BCE) was a sophist who was well-known in the Platonic dialogues Hippias Major and Hippias Minor for his arrogance and assumed knowledge. In the latter dialogue in particular, where Plato debates the deficiency of human knowledge, the character of Hippias is depicted as ridiculous because of his vanity. Hippias plays a decisive role in the final part of Socrates, as he is convinced that disclosing the truth would be much more harmful to people than keeping them believing in life's many lies, illusions, and falsities. He also appears in Luzzatto's Discourse, in a passage in which he discusses two forms of falsity: voluntary lies on the one hand, and those lies ("which have a more monstrous appearance") produced by the mind when turbid passion and dark ignorance match the will on the other. In this regard, Luzzatto is explicitly referring to Hippias Minor, underlying that in this dialogue in particular, Plato rejected this kind of lie more than any other. See Discourse, 43v.

15 Timon of Athens (fifth century BCE) became well-known for his misanthropy. Diogenes Laertius and Plutarch are the main sources for his life. He inspired many works both in antiquity and in the early modern period, such as Timon or the Misanthrope by Lucian of Samosata, Matteo Maria Boiardo's comedy Il Timone (1487), and William Shakespeare's play Timon of Athens (1608). Along with Hippias, he plays a crucial role in the final part of Socrates by maintaining his legendary status as an angry despiser of humankind. The adjective "Timonian" also occurs once in Luzzatto's Discourse (50r) to describe a kind of hatred that is "greater than Timonian" motivating the Amalekites in their attempt to exterminate humanity.

16 In Socrates, the term author must be always read with the specific meaning of the one who gives Authority, which is one of the main issues debated throughout the book.

17 Dante, Purgatory, 3.79-84. Dante is quoted three times in Socrates (see also 32; 88-89). It was very common to mention the Divine Comedy in seventeenth-century Italian literature as there were many editions published in sixteenth- and seventeenth-century Italy. The last edition was published in Venice in 1629 by Nicolò Misserini. Dante's influence on Jewish literature may be seen in the Hebrew works of some poets of the fourteenth and fifteenth centuries such as Immanuello Romano, Yehuda Romano, Moshe da Rieti, and Achituv da Palermo. See Ariel Viterbo, "Socrate nel ghetto: lo scetticismo mascherato di Simone Luzzatto," Studi veneziani 38 (1999): 96; Giuseppe Tavani, Dante nel Seicento (Florence: Olschki, 1976); Joseph B. Sermoneta, "Dante Alighieri," in Encyclopedia Judaica, ed. Cecil Roth (Jerusalem: Macmillan, 1971): 5:1295-96.

18 Pythagoras and Aristotle and their disciples are here recalled by Luzzatto as important examples of proponents of dogmatic wisdom whose authority was strengthened by their followers, who appealed to their masters' teachings rather than to evidence and reason. The ipse dixit ("he himself said so") form introduces the concept of authority into the philosophical debate. Such authority was first em- 
bodied by the figure and teachings of Pythagoras. See Cicero, On the Nature of the Gods 1.10: "Those however who seek to learn my personal opinion on the various questions show an unreasonable degree of curiosity. In discussion it is not so much weight of authority as force of argument that should be demanded. Indeed the authority of those who profess to teach is often a positive hindrance to those who desire to learn; they cease to employ their own judgment, and take what they perceive to be the verdict of their chosen master as settling the question. In fact I am not disposed to approve the practice traditionally ascribed to the Pythagoreans, who, when questioned as to the grounds of any assertion that they advanced in debate, are said to have been accustomed to reply 'He himself said so,' 'he himself' being Pythagoras. So potent was an opinion already decided, making authority prevail unsupported by reason." In the Middle Ages and the Renaissance, ipse dixit was used when referring to Aristotle's philosophy. See Galileo Galilei, Dialogue concerning the Two Chief World Systems, 2nd day, 108: "SAGREDO: Doubtless it never will be, in the minds of such opponents. But what you say does not in the least diminish the absurdity of this Peripatetic's reply; who, as a counter to sensible experience, adduced no experiment or argument of Aristotle's, but just the authority of his bare ipse dixit."

19 We have translated the vernacular istanza (Latin instantia), used in Scholastic Logic, as "case adduced in objection to"; see Oxford English Dictionary, s. v. "instance."

20 Aristarchus of Samos (ca. 310-ca. 230 BCE) was a Greek mathematician and astronomer known for having been the first person to assert that the earth and the other planets revolved around the sun. 21 Luzzatto is referring to Herostratus the arsonist, who in 356 BCE burned down the Temple of Artemis at Ephesus, known as one of the seven wonders of the world, merely to immortalise his name. During the sixteenth and seventeenth centuries, he was usually cited as a symbol of someone who would rather pursue a great reputation than a good one, also mentioned by Montaigne in his Essays $(2: 16,655)$. Nevertheless, one should consider that Herostratus was subjected to a damnatio memoriae, so it was forbidden even to mention his name (see Valerius Maximus, Nine Books of Memorable Deeds and Sayings 8.14.5). For this reason, most classical authors would talk about him whilst omitting his name, as Lucian (The Passing of Peregrinus 22), Plutarch (Parallel Lives: Alexander 3.665), and Cicero (On the Nature of the Gods 2.27.69) did.

22 Theaetetus (ca. 417-368 BCE) was an Athenian mathematician and the protagonist of Plato's dialogue Theaetetus. In the dialogue, Socrates and Theaetetus discuss the nature of knowledge, come to the aporetic conclusion that they are unable to define it because of the many contrary opinions, and thus decide to continue discussing the topic the next day.

23 Gorgias (ca. 480-ca. 380 BCE), a native of Leontini in Sicily, is considered the father of sophistry and also known by the epithet "the Nihilist." Indeed, among his rhetorical works may also be listed On Nature or the Non-Existent, the original text of which was lost but which was partially preserved by Sextus Empiricus in Against the Professors and by the anonymous author of On Melissus, Xenophanes, and Gorgias. Gorgias is also one of the characters of the Platonic dialogue which shares his name, in which Socrates discusses the essence of rhetoric with him.

24 Laches, an Athenian general and statesman, is one of the participants of the Platonic dialogue Laches, which discusses the nature of courage.

25 Euthyphro, along with Socrates, is the protagonist of the Platonic dialogue which shares his name in which the definition of piety is debated. The dialogue also became famous for the dilemma "Is the pious loved by the gods because it is pious, or is it pious because it is loved by the gods?" (10a), which profoundly impacted the philosophical debate on the monotheistic religions.

26 Themistocles (ca. 524-ca. 460 BCE) was an Athenian general and statesman who strengthened Greece's naval and military power during the Persian wars, thereby assuring its victory. The three notable ancient sources for his life are Herodotus, Thucydides, and Plutarch. While the first two praised his quick wits in political and military strategies, Plutarch depicted him as a skilful leader who was nevertheless extremely ambitious and thirsty for power at any cost.

27 In the early modern era, Descartes and others likened Scepticism to a disease. In Descartes's view, Scepticism was an illness that could only be cured by his philosophy. This medical metaphor is also 
used by Sextus, but according to him, the disease consists in dogmatic knowledge, while the cure is Scepticism. See Gail Fine, "Descartes and Ancient Skepticism: Reheated Cabbage?” The Philosophical Review 109, no. 2 (April 2000): 199.

28 Xenophon (ca. 430-354 BCE) was a philosopher, historian, soldier, and disciple of Socrates. Along with Plato, he devoted several of his writings to his master, for example, Memorabilia and an Apology of Socrates to the Jury.

29 The phoenix is a legendary bird which gains new life by arising from its own ashes after its death and thus being reborn.

30 Antaeus was a Libyan giant who compelled all strangers passing through the country to wrestle with him. According to the myth, whenever Antaeus was thrown to the ground and touched his mother, the Earth, he increased his strength and was therefore invincible. Heracles discovered the source of his strength and defeated him.

31 See Sextus Empiricus, Outlines of Scepticism 1.81: "There was (so they say) an old woman in Attica who consumed four ounces of hemlock without harm."

32 Anytus and Meletus were two of the three accusers of Socrates (along with Lycon), as stated by Plato in his Apology, where Meletus is presented as an opponent of Socrates on behalf of the poets, Anytus on behalf of the craftsmen, and Lycon on behalf of the rhetoricians. Lycon is absent from Luzzatto's book, but the reason for his absence is not immediately evident.

33 Protagoras (fifth century BCE) was a native of Abdera and one of the first sophists. The Platonic dialogues are one of the main sources of his philosophical teachings, one of which is named after him. His famous statement "man is the measure of all things" (also mentioned by Luzzatto; see Socrates, 14) argues for individual relativity against the assumption of the existence of an objective truth.

34 See Plato, Theaetetus 152a: "Socrates: And, indeed, if I may venture to say so, it is not a bad description of knowledge that you have given, but one which Protagoras also used to give. Only, he has said the same thing in a different way. For he says somewhere that man is 'the measure of all things, of the existence of the things that are and the non-existence of the things that are not." The same passage also occurs in Sextus Empiricus, Outlines of Scepticism 1.56.

35 On this topic, see the dialogues with Crito and the mirror maker on pages 64-77.

36 The phrase "citizen of the universe" was coined by Diogenes of Sinope, known as Diogenes the Cynic, who was quoting the way in which Socrates would answer when asked about his origins. A wellknown passage from Epictetus testifies that when Socrates was asked to what country he belonged, he did not answer '“I am an Athenian,' or 'I am a Corinthian,' but 'I am a citizen of the universe'” (Epictetus, Discourses 1.9.1-2). Generally, the topic of cosmopolitism, joined with the Socratic statement of being a citizen of the universe or Cosmian, is widely present in classical authors between the first century BCE and the first century CE: see Cicero, Tusculan Disputations 5.37.108 and Plutarch, On Exile 5, 600F.

37 On the comparison between sceptical inquiry and medical treatment, see Sextus Empiricus, Outlines of Scepticism 3.280-81: "Sceptics are philanthropic and wish to cure by argument, as far as they can, the conceit and rashness of the Dogmatists. Just as doctors for bodily afflictions have remedies which differ in potency, and apply severe remedies to patients who are severely afflicted and milder remedies to those mildly afflicted, so Sceptics propound arguments which differ in strength - they employ weighty arguments, capable of vigorously rebutting the dogmatic affliction of conceit, against those who are distressed by a severe rashness, and they employ milder arguments against those who are afflicted by a conceit which is superficial and easily cured and which can be rebutted by a milder degree of plausibility." In contrast to the early modern idea of Scepticism as a disease to be cured, here Sextus conceives dogmatism as the disease that Scepticism will cure.

38 This echoes the position of Luzzatto's book, expressed in the volume's subtitle.

39 Luzzatto is here referring to one of the main aspects of Carneades's Academic Scepticism whereof Cicero's Academics is the chief source, in which the Roman philosopher and statesman translated the Greek word pithanon (convincing, persuasive) as probabile in Latin, setting the stage for the Sceptics' 
instruction to follow the probable in the absence of truth. See Charles B. Schmitt, Cicero Scepticus: A Study of the Influence of the Academica in the Renaissance (Dordrecht: Springer, 1972).

40 Sextus Empiricus's criticism of Dogmatics mentions that every dogmatic statement is subject to irreconcilable conflicts (diaphōnia); see Emidio Spinelli, "Sceptics and Language: Phōnaí and Lógoi in Sextus Empiricus,” Histoire Épistémologie Langage 13, no. 2 (1991): 65.

41 Cratylus was probably an Athenian who lived during the fifth century BCE. He was a follower of Heraclitus's doctrine and his teaching deeply impacted the philosophy of Plato, who made him one of the main characters of Cratylus, a dialogue focusing on whether names can correctly express the essences of the subjects to which they refer.

42 Xenophanes (ca. 570-ca. 475 BCE), a native of Colophon, was a philosopher, poet, and theologian. He is considered one of the most important Pre-Socratic philosophers, known for his satire against the polytheism and anthropomorphism of traditional religion and as one of the first to reflect on the distinction between true belief and knowledge. According to some other commentators, his teachings influenced Parmenides and he was a forerunner of the Eleatic school.

43 Melissus of Samos (fifth century BCE) was a member of the Eleatic school. He shared most of Parmenides's claims concerning being, but unlike him, he considered it unlimited and eternal.

44 Dante, an author whom Luzzatto held in high esteem, mentions the Greek myth of Medusa in Hell, 9.55-57: "Now turn your back and cover up your face; if the Gorgon appears and you catch sight of her you will never go back to the world again."

45 Parmenides (fifth century BCE) was born in the Greek colony of Elea and was the founder of the Eleatic school. Under the conventional title On Nature, we have (in fragmentary form) his only surviving work. Here, he distinguished between the true reality and that of opinion or illusion, expressed through the famous statement that "What Is is; for it is to be, but nothing it is not." His monistic position was supported by the claim that what exists is one being, ungenerated, indivisible, changeless, motionless, limited, and timeless. Parmenides is also the title of one of Plato's most enigmatic dialogues, focusing on a critical examination of the theory of forms, according to which there is a single, unchanging, indivisible, non-sensible, and eternal form corresponding to every property and forms are not identical to the things that partake of or are related to them.

46 Luzzatto repeats this sentence on page 294 of the original, where he discusses the concept of glory. The perceptions of the senses being dreams for the waking and deliriums for those of sound mind appears in a similar statement in Seneca's Epistles 53, quoted in Montaigne's Essays (3:5, 860-61). It is possible to find a very close expression in Augustine of Hippo's City of God 10.25. By referring to Job (20:8), Augustine describes the vanity of the civitas terrena as "the summit of temporal prosperity had been changed for them to a sort of dream from which the dreamer wakes and suddenly finds himself stripped of the illusory joys that were his while he dreamed."

47 Heraclitus, a native of Ephesus, was known to have shifted his attention from cosmic to human affairs. He advocated the doctrine of flux, which entails the coincidence of opposites (involving the contradiction that the unity of opposites leads to the admission that things are both the same and not the same over time). According to him, fire is the first principle of all things and changes into the other elements following a cosmic cycle. Although Plato interpreted Heraclitus's doctrine of the flux of sensibles as a negation of any possibility of acquiring knowledge, he nevertheless seemed inclined to believe that not all people can attain wisdom, but only those who are able to discern it. Later he was depicted as the "weeping philosopher" (Heraclitus flens), and with Democritus, known as the "laughing philosopher" (Democritus ridens), he formed a famous duo used to describe the human condition, as is also testified by Montaigne's Essays (1:50, 339-41). During the Renaissance, the two philosophers were usually connected to the concept of theatrum mundi (The Great Theatre of the World), a typical baroque expression meant to emphasise the world's vanity and futility. See Flemming Schock, Oswald Bauer, and Ariane Koller, eds., Dimensionen der Theatrum-Metapher in der Frühen Neuzeit. Ordnung und Repräsentation von Wissen (Hannover: Wehrhan Verlag, 2008).

48 On Heraclitus and fire, see also Luzzatto, Discourse, 81r. 
49 Anaximenes (sixth century BCE) was a native of Miletus and considered one of the three Milesian philosophers. He believed that air was the primary substance from which all things are composed.

50 Thales (first half of sixth century BCE) is deemed to be the first of the Milesian philosophers, and according to many, including Aristotle himself, he was the first philosopher of the Greek tradition. He believed water to be the single material substance at the origin of all things.

51 The Eridanus was a river described in Greek mythology as the son of Oceanus and Tethys, identified with the Po or the Rhone (France). According to legend, Phaeton, the son of Helios, fell in the river and died after losing control of the sun chariot and being struck down by Zeus's lightning in order to prevent him from burning down the earth.

52 Orpheus was a legendary poet, son of the Muse Calliope and the Thracian king Oeagrus. He was well-known for the magical power of his music and his lyric poetry. In the Christian era, Orpheus was represented as a good shepherd surrounded by wild and tame animals fascinated by his music.

53 Empedocles (ca. 490-430 BCE) was a Pre-Socratic philosopher and poet from Agrigentum. He explained worldy existence as the result of the constant collision and separation of the four elements driven by two attractive and repulsive forces, love and strife.

54 Democritus (ca. 460-360 BCE), a disciple of Leucippus, was considered one of the founders of atomism, which attempted to give a materialistic and mechanistic explanation of world's natural laws without resorting to the prime mover and final goal.

55 On Democritus as a "laughing philosopher," see footnote 47.

56 On the concept of theatrum mundi, see footnote 47.

57 Anaxagoras (500-428 BCE), who originated from Clazomenae, believed that there originally existed an infinite number of original seeds that were inextricably combined together in a confused form throughout the universe. These seeds are homogeneous or, according to the Aristotelian definition, homoiomerous, that is, "like-parted." Anaxagoras addressed the task of ruling and arranging them, as well as the role of cause and preserver of cosmic order, to a Mind or Reason (Nous) endowed with all knowledge and power. Contrary to Democritus, Anaxagoras advocated the theory of the infinite divisibility of matter; see Socrates, 79-83.

58 The same image also occurs in Montaigne's Essays (2:12, 571). It was a deist's claim that the universe could not have come into existence by the fortuitous combination of atoms as that Homer's Iliad could have been produced by an accidental combination of letters, see Peter Jimack, "The French Enlightenment I: Science, Materialism and Determinism," in British Philosophy and the Age of Enlightenment, ed. Stuart Brown (London: Routledge, 1996), 244.

59 This same concept of a Mind as the ordering force of Chaos may also be found in the philosophies of Bernardino Telesio, Tommaso Campanella, and Giordano Bruno, which were probably inspiring theoretical sources for Luzzatto.

60 Argus was a mythological giant, the guardian of Io (who was transformed into a heifer by Zeus), whose epithet was "all-seeing" (panoptēs) as he was described as having multiple eyes. He was thus often mentioned in literature for his wakeful alertness. The reference to all-seeing Argus is also repeated below, 236 .

61 Luzzatto often refers to philosophers' opinions as things that they envisioned (literally "dreamt"). This expression was coined during antiquity with reference to the theory of atomism: Cicero, in Academics $(2.38,121)$, uses it when criticising Strato for his belief in atomism, namely that Democritus somniavit, while Lactantius (The Divine Institutes 3.17.23) used it in reference to Leucippus. This statement recurs as a topos in the early modern period and a specific example of it also appeared in Luzzatto's Discourse (26r), where he describes the infinite worlds of Democritus as "the envisioned worlds of Democritus.”

62 On the three basic principles of privation, matter, and form, see Aristotle, Physics 1.7.

63 On alchemists in Luzzatto's time, see Daniel Jütte, Das Zeitalter des Geheimnisses. Juden, Christen und die Ökonomie des Geheimen (1400-1800) (Göttingen: Vandenhoeck \& Ruprecht, 2011), 61-75. 
64 Luzzatto may have been referring to Costantino Saccardini, Libro nomato la verità di diverse cose: quale minutamente tratta di molte salitufere operationi spagiriche, et chimiche (Bologna: Gio. Paolo Moscatelli, 1621), 9.

65 It is not surprising that Luzzatto should refer to chess, a game dearly beloved by the Jewish people of his time, especially because it was even permitted on a Saturday. There is a great deal of literature and bibliography on this topic, from the classic study by Moritz Steinschneider, Schach bei den Juden: ein Beitrag zur Cultur- und Litteraturgeschichte (Berlin: Julius Springer, 1873) to Victor A. Keats, Chess in Jewish History and Hebrew Literature (Jerusalem: Magnes Press, 1995).

66 We have translated the vernacular scandaligiarmi (from scandaglio, coming from the medieval Latin word scandalium) as "to scrutinise." This kind of examination which goes into itself in depth is an important aspect of ancient sceptical thinking. After giving up the sensorial knowledge of Nature, the Sceptics took the path of subjectivity, the internal senses, and human knowledge. The ancient Sceptics, following Socrates and Plato's doctrine, dedicated themselves to a careful study of the passions of the soul. They encouraged new psychological, epistemological, and anthropological research. See Antonio Russo, ed., Scettici antichi (Torino: UTET, 1978), 17.

67 The same issue also occurs in Montaigne's Essays (2:12, 348-49), where he attributed this opinion to Democritus.

68 The capacities of animals to overcome human techniques was a recurring topic in early modern literature; see Montaigne's Essays 2:12. 480-82.

69 Literally "emphasis of light and profundity of dark."

70 A similar passage also occurs in Montaigne's Essays (1:34, 261-62).

71 The centre of gravity was a traditional subject studied using Archimedes's method. The important study by Luca Valerio (1552-1618), De centro gravitatis solidorum. Libri Tres (Roma: Bartholomaei Bonsadini, 1603), was highly praised by Galileo - who described Valerio as "the Archimedes of our age" and also influenced Galileo's treatment of the centre of gravity of solids published in the appendix of his Two New Sciences (1638). See Carlos Hernan Wörner and Godofredo Iommi-Amunátegui, “Galileo’s Treatment for the Centre of Gravity of Solids," European Journal of Physics 28 (July 2007): 643-48.

72 Luzzatto is paraphrasing the Latin proverb mater necessitas artium ("necessity is the mother of invention"); see also Luzzatto, Discourse, 18r, and Giuseppe Veltri, "Economic and Social Arguments and the Doctrine of the Antiperistasis in Simone Luzzatto's Political Thought: Venetian Reverberations of Francis Bacon's Philosophy?” Frühneizeit 23 (2011): 23-32.

73 Lucretius, On the Nature of Things 4.513-21. Luzzatto's quotation lacks verse 514: "If the level is a trifle wrong in any part" (et libella aliqua si ex parte claudicat hilum). The full quotation occurs in Montaigne's Essays 2:12, 627.

74 In Scholastic logic, an "instance" (medieval Latin instantia) was an argument adduced in order to reject a universal assertion. It recurs throughout Socrates in this sense.

75 Avicenna recognises a reflective type of self-awareness that he characterises as awareness of awareness (šu'ūr bi-al-šu'ūr), and he recognises the capacity for "knowing that we know" as a distinctive form of self-knowledge; see Deborah L. Black, "Avicenna on Self-Awareness and Knowing That One Knows," in The Unity of Science in Arabic Tradition, ed. Shahid Rahman, Tony Street, and Hassan Tahiri (Dordrecht: Springer 2008): 63-87; Jari Kakua, Self-Awareness in Islamic Philosophy: Avicenna and Beyond (Cambridge: Cambridge University Press, 2015).

76 Luzzatto is here referring to the "Delian problem," the "doubling of the cube," which, according to some interpreters, is referenced by Plato in his Republic (7.528b). Plutarch (On the E at Delphi 386E and On the Genius of Socrates 579B-D) recounts how Plato was asked to explain the enigmatic Delphic Sybil's answer, according to which the citizens of Delos and all of Greece would find relief from their pains only when they were able to double the god's cubic altar. Plato explained that trying to follow the god's order literally was a vain attempt: according to him, Apollo was mocking the Greeks' ignorance, since the Delphic Sybil's answer should have been interpreted as an exhortation to the study of mathematics and geometry. 
77 See Aristotle, Nicomachean Ethics 5.2.1130b30-33, where the distinction between distributive justice and corrective justice was first debated.

78 Ovid, Metamorphoses 3.432.

79 "Genus of relative" from the vernacular genere della relatione, plausibly from Latin genus relationis; see Ludovico Rodriguez, Dialecticae Aristotelis compendium commentaria, pluresque articuli (Salamanca: Antonia Ramirez, 1624), 394; Martinus Smiglecius, Logica (Oxford: Guil. Turner pro. Hen. Crips, 1638), 378. A reference to the category of relative also occurs in Luzzatto's Discourse, 82r, which discusses Sextus Empiricus's eighth mode, namely the one deriving from relativity (see Sextus Empiricus, Outlines of Scepticism 1.135-44). On this topic, see Veltri, Alienated Wisdom (Berlin: De Gruyter, 2018), 218-24.

80 This is an example of isostheneia, equipollence, which consists in the equal reliability of opposing judgments. According to Sextus, Scepticism causes a standoff of equipollence which demands the suspension of judgment. See Sextus Empiricus, Outlines of Scepticism 1.8-10, 190, 196, 200.

81 Tantalus, a mythological figure, was destined for a state of eternal dissatisfaction because of his offences against the gods. His punishment was to remain in a pool of water underneath a fruit tree, but to be unable either to drink the water, which receded every time he tried to drink it, or to eat the fruit, because the branches of the tree would rise whenever he tried to grasp them.

82 Dante, Paradise, 4.1-6. Through this quote, Luzzatto seems to be playing on Buridan's ass, a philosophical paradoxical conception of free will according to which a hungry and thirsty donkey is placed precisely midway between a stack of hay and a pail of water. As it is assumed that the ass will always go towards whichever is closer, it dies of both hunger and thirst since it cannot make a decision.

83 Nothingness was also a widely debated topic among the disputations of the Accademia degli Incogniti, with which Luzzatto was presumably in contact; see Veltri and Chayes, Oltre le mura del Ghetto; Torbidoni, "Italian Academies." On nothingness within the Accademia degli Incogniti, see Luigi Manzini, Il Niente. Discorso (Venice: Andrea Baba, 1634); Marino Dall'Angelo, Le Glorie del Niente. Discorso (Venice: Sarzina, 1634); Carlo Ossola, Le antiche memorie del nulla (Rome: Edizioni di Storia e Letteratura, 2007).

84 Gorgias may be referring, among others, to On Nature or the Non-Existent, see footnote 23.

85 Luzzatto may have read Giordano Bruno's De Umbris Idearum (Paris: E. Gourbin, 1582).

86 Aristotle, in Metaphysics 4.2.1003a33-b16, discusses whether there may be a science of being as such if being itself is not a genus. That being is not a genus is developed in Aristotle's Metaphysics 3, followed by the question of how knowledge may deal with the substance and the accident if there is no genus able to encompass both of them. The issue is debated by Thomas Aquinas in his Commentary on the Metaphysics III, lect. 8, n. 433.

87 Endymion was a mythological figure who, according to Hesiod, was held in high esteem by Zeus, who decided to grant him the privilege to choose the way in which he would die. Yet as soon as Endymion showed desire for Hera, Zeus punished him by throwing him into the Underworld, or, according to some other sources, he caused him to fall asleep for eternity.

88 See Sextus Empiricus, Outlines of Scepticism 3.39, where Sextus discusses whether bodies are apprehensible and examined the weak position of those who claimed that a body is something threedimensional that has resistance (the addition of resistance is ascribed to Epicurus; see Sextus Empiricus, Against the Mathematicians 11.226). See Ian Mueller, "Geometry and Scepticism," in Science and Speculation, ed. Jonathan Barnes, Jacques Brunschwig, Myles F. Burnyeat, and Malcolm Schofield (Cambridge: Cambridge University Press 1982): 69-95; Keimpe Algra and Katerina Ierodiakonou, eds., Sextus Empiricus and Ancient Physics (Cambridge: Cambridge University Press, 2015).

89 Zeno (fifth century BCE) was an Eleatic philosopher and a friend and disciple of Parmenides, particularly known for his paradoxes. The most famous are the arguments against motion, which Aristotle refers to in his Physics 6.9. 
90 Luzzatto is probably referring to Carneades, who denied causal determinism and fate. Carneades argued against the Stoics, who believed in an everlasting ordering and connection of causes. See Cicero, On Fate 11; Tim O'Keefe, Epicurus on Freedom (Cambridge: Cambridge University Press, 2005). 91 Aristippus (ca. 430-355 BCE) was a disciple of Socrates and the founder of the Cyrenaic school of philosophy. Several sources, such as Diogenes Laertius, Xenophon, and Plato, identified him as a follower of hedonistic philosophy and an opponent of Socrates's view.

92 See Aristotle, Physics 4.8.215a2-b23, on projectile motion. The topic also occurs in Socrates, 130.

93 According to ancient and medieval mythological traditions, incubi were demons who lay on top of people while they were asleep, producing nightmares.

94 Luzzatto is referring to Aristotelian cosmology.

95 Lucretius, On the Nature of Things 4.216-17.

96 Lucretius, 4.230-36

97 This issue as proof of man's impudence was also discussed by Montaigne (see Essays 2:12, 475-79). 98 The same example occurs in Sextus Empiricus, Outlines of Scepticism 1.44: "But it is the differences among the most important parts of the body, especially those which are naturally fitted for deciding and perceiving, which can produce the greatest conflict of appearances. For instance, people with jaundice say that what appears white to us is yellow."

99 The medical condition of vertigo was explored and examined by Galen, whose medical teachings spread following the Latin translation of some of his treatises made by Gerardo of Cremona (1134-87). The medical treatise by Guglielmo of Saliceto (1210-76), Summa conservationis et curationis, which was printed in Piacenza in 1476 and published many times in Venice, Milan, Leipzig, and Lyon, was profoundly impacted by Galenic tradition. In this book, vertigo was described as a sense of the rotation of objects or the head caused by vapours and the excessive presence of one humour over the others. This interpretation was still held to be valid in the Renaissance; see Jole Agrimi and Chiara Crisciani, "The Science and Practice of Medicine in the Thirteenth Century according to Guglielmo of Saliceto, Italian Surgeon," in Practical Medicine from Salerno to the Black Death, ed. Luis Garcià-Ballester (Cambridge: Cambridge University Press, 1994), 60-87.

100 Luzzatto seems to be referring to the principles of Euclidean geometrical optics. The idea that the figure perceived by visual rays is a cone which has its radial tip in the eyes and its base in the object is the second postulate of Euclid's Optics.

101 Genius is traditionally interpreted as a protective divinity external to man, or as a concept, a deified personality, located on a person's brow, which represents the innate qualities of a person, namely the person's creative force. See, for example, Franz Altheim, A History of Roman Religion, trans. Harold Mattingly (London: Methuen, 1938), 59 and passim.

102 Galen discusses an abundance of black bile as the cause of melancholy in his Commentary on Hippocrates' Aphorisms 3.22 (17b 622.2-6 K); see Jacques Jouanna, "At the Roots of Melancholy: Is Greek Medicine Melancholic?” in Jouanna, Greek Medicine from Hippocrates to Galen, ed. Philip van der Eijk, trans. Neil Allies (Leiden: Brill, 2012), 229-58. On melancholy, see the classic extensive study collected in Raymond Klibansky, Erwin Panofsky, and Fritz Saxl, eds., Saturn and Melancholy: Studies in the History of Natural Philosophy, Religion and Art (London: Nelson, 1964). For the Jews and melancholy specifically, see Eric Zafran, "Saturn and the Jews," Journal of the Warburg and Courtauld Institutes 42 (1979): 16-27; Moshe Idel, Saturn's Jews: On the Witches' Sabbat and Sabbateanism (New York: Continuum, 2011); Eliezer Gutwirth, "Jewish Bodies and Renaissance Melancholy: Culture and the City in Italy and the Ottoman Empire," in The Jewish Body: Corporeality, Society, and Identity in the Renaissance and Early Modern Period, ed. Maria Diemling and Giuseppe Veltri (Leiden: Brill, 2009), 57-92. 103 In Greek mythology, Byblis was known as the daughter of Miletus and Eidothea. She decided to go into exile, where she died, because she was in love with her twin brother Caunus. However, Ovid narrates that she turned into a spring, being dissolved in her own tears. A reference to Byblis also occurs in Socrates, 121.

104 Ovid, Metamorphoses 9.479-86. 
105 To live by experience and without opinions plays a relevant role in Sextus's arguments against dogmatic assertions; see Outlines of Scepticism 2.246.

106 The reference to the Egyptians' worship of animals also occurs in Discourse, 65v, where Luzzatto quoted Juvenal, Satires 15.1-4. The same topic, together with the same quotation, is provided by Montaigne's Essays in 2:11, 462-64.

107 This quotation is a combination of two verses of different origins: the first verse - "[Death] either was or is to come: nothing of the present is in her" (Aut fuit aut veniet, nihil est prasentis in illa) - is from Satires, a Latin poem written by Étienne de la Boétie and addressed to Montaigne (number 20, "Ad M. Montanum”), See Étienne de la Boétie, Oeuvres complètes, ed. Louis Desgraves (Périgueux: William Blake \& Co., 1991): 71. The second verse - "And death holds less of dole for me than the delay of death" (Morsque minus pena quam mora mortis habet) - is from Ovid, The Heroines 10.82. The two verses have been quoted together also by Montaigne (see Essays 1:14, 103).

108 Mayflies are insects which belong to the order Ephemeroptera; they live for only a few hours or up to a day.

109 This proverb is also found in Erasmus of Rotterdam's Adages $(564,1.6 .64)$, in which the idea that crows have a lifetime that is nine times longer than that of humans is attributed to Hesiod.

110 Hero and Leander, according to Ovid in Heroines (books 18 and 19), lived in Abydos in Asia Minor. Leander was in love with Hero, a priestess of Aphrodite in Sestos on the European coast. Every night, he swam across the strait in order to meet her. On one occasion, when a storm extinguished the oil lamp that Hero would prepare for him each night, Leander became disorientated and drowned. At dawn, Hero saw him on the beach and jumped from the tower in desperation.

111 Ovid, Heroines 19.65.

112 Concerning the comparison between counterfeit coins and untruthful opinions, see Giuseppe Veltri, Renaissance Philosophy in Jewish Garb (Leiden and Boston: Brill, 2009), 86n71.

113 Luzzatto's argument about the impossibility of deciding who may be wise enough to judge whether something is true or false is a version of the Sceptical critique of the possibility of finding a criterion of judgment. For instance, in describing the fifth mode that depends on positions, intervals, and places, Sextus argues that "anyone wishing to give preference to some of these appearances over others will be attempting the impossible. If he makes his assertion simply and without proof, he will not be convincing. But if he wants to use a proof, then if he says that the proof is false, he will turn himself about; and if he says that the proof is true, he will be required to give a proof of its being true, and another proof of that (since it too has to be true), and so ad infinitum. But it is impossible to establish infinitely many proofs. And so he will not be able to prefer one appearance to another with a proof either" (Outlines of Scepticism 1.121-22). See Pamela M. Huby and Gordon Neal, eds., The Criterion of Truth (Liverpool: Liverpool University Press, 1989).

114 Cupellation was the process used in the Middle Ages and Renaissance to separate noble metals from base metals.

115 This is a reference to Aristotle's four causes: the material, the formal, the efficient, and the final; see Physics 2.3, Metaphysics 5.2.

116 Regarding "executive motion," Luzzatto is indirectly quoting Thomas Aquinas, Summa Theologica, II-I, Q. 31, Art. 1.

117 This is a reference to the statue of Zeus at Olympia made by Phidias, considered one of the seven wonders of the ancient world, as also testified by Strabo in his Geography 8.3, 354 and Pausanias, Description of Greece 5.2.

118 We have translated the vernacular verisimile as "resembling the truth." On this topic, see Veltri, Alienated Wisdom, 213.

119 Luzzatto is referring to one of the most famous classical cameos, made of Sicilian agate, representing Apollo and the nine Muses and belonging to King Pyrrhus: "After this ring, the most renowned gemstone is that of another king, the famous Pyrrhus who fought a war against Rome. He is said to have possessed an agate on which could be seen the Nine Muses with Apollo holding his lyre. Apart 
from these stones, my authorities can produce no gems famous enough to be specially recorded.” (Pliny the Elder, Natural History 37.3).

120 This statement seems to recall Ockham's principle, whereof the best-known version was "entities are not to be multiplied without necessity" (Non sunt multiplicanda entia sine necessitate), written by the Franciscan philosopher John Punch in his commentary on Duns Scotus's work published in 1639. See Johannes Poncius, Commentary on John Duns Scotus' Opus Oxoniense, book 3, dist. 34, q. 1, in John Duns Scotus, Opera Omnia, vol. 12 (Lyon: Luke Wadding, 1639).

121 The Elean Stranger was a character in the Platonic dialogues the Sophist and the Statesman. He was a philosopher from Elea who criticised Parmenides's ontology, which denies the possibility of speaking and thinking about non-being.

122 See Plato, Sophist 236d-264b, which refers to being, sameness, difference, motion, and rest as the great kinds of things.

123 On the metaphor of Scepticism as a purgative medicine, see Sextus Empiricus, Outlines of Scepticism 1.206; 2.188. It also occurs in Socrates, 287; see also footnote 502.

124 Circe was a famous goddess and enchantress in Greek mythology known for transforming her enemies into wild beasts thanks to her vast knowledge of potions and herbs. In one episode of Homer's Odyssey (10.210), she turned Odysseus's crew into swine after they drank from her enchanted cup.

125 The tortoise and the snail (see also Socrates, 277) were metaphorically adopted from the Middle Ages onwards to symbolise sloth; see Siegfried Wenzel, The Sin of Sloth: Acedia in Medieval Thought and Literature (Chapel Hill: University of North Carolina Press, 1960; repr. 1967).

126 On genius, see footnote 101.

127 "Virtue" has been corrected to "vision" in the marginalia because it is more consistent with the discussion provided by this passage.

128 Crito was a disciple and friend of Socrates. He is a character in the Platonic dialogue which shares his name in which he tries to persuade Socrates to break the rules and escape from prison. Crito appears also in the well-known final part of another dialogue, Phaedo, where Socrates asks him to offer a cock to Asclepius, god of medicine, before his death.

129 Experience with Crito who, blind, denied the sense of vision.

130 We have translated the vernacular dubitando as "I suspected," because it is more idiomatic.

131 Luzzatto seems to be referring to the emission theory of vision, which maintains that visual rays emanate from the eyes and are intercepted by external objects; Euclid's (Optics, definitions 1 and 2) and Ptolemy's (Optics) accounts of vision are based on this model.

132 Luzzatto seems to be recalling the atomistic theory of vision attributed to Leucippus, Democritus, and Epicurus, which maintains that sight occurs through simulacra entering the eyes. See Aristotle, Sense and Sensible Objects 2.438a5-439a6; Lucretius, On the Nature of Things 2.26-447. Theophrastus, in his De sensibus 50-54 states that according to Democritus, the production of simulacra may be explained as a physical impression, or even a stamped impression, made by copies shed by visible objects. See J.B. McDiarmid, “The Manuscripts of Theophrastus' De Sensibus,” Archiv für Geschichte der Philosophie 44, no. 1 (1962): 1-32.

133 See Aristotle, Metaphysics 4.3, which refers to the principle of contradiction.

134 See Aristotle, On the Soul 2.12, in which he defines perception as the reception of form without matter, explaining it through the analogy of a gold signet ring impressing a block of wax.

135 The Greek concept of idea as image is translated into Latin as species, from specio, in the specific sense of watching in order to gain knowledge of what one is observing. The term therefore retains a strong ontological and gnoseological meaning, preserving the dynamism of vision as an exchange between subject and object. See Giorgio Stabile, Teoria della visione come teoria della conoscenza, in Stabile, Dante e la filosofia della natura: percezioni, linguaggi, cosmologie (Florence: SISMEL Edizioni del Galluzzo, 2007), 12-13.

136 The visual cone is examined by Euclid, Optics, postulate 2, and Ptolemy, Optics 2.20. 
137 Luzzatto is here referring to Plato's account of visual theory described in the Timaeus; according to this position, the emission of the rays would be doubled, one from the eye, which melds with daylight and forms a kind of percipient medium, and the other from the visible objects. Concerning this topic, see David C. Lindberg, Theories of Vision from Al-Kindi to Kepler (Chicago: University of Chicago Press, 1981), especially $1-6$.

138 The statement that animals' perceptions excel those of human beings and the following arguments are taken from Sextus Empiricus. See Outlines of Scepticism 1.62-64, 76-77.

139 Concerning "hydrographic maps," see Jacques Severt, De Orbis Catoptrici seu mapparum mundi principiis, description ac usu. Libri tres (Paris: Baltasar Morel, 1590), 23.

140 See pseudo-Aristotle, Plants 1.815a17-b35.

141 Luzzatto seems to be referring to a plant called Mimosa pudica (Touch-me-not), which was nicknamed "the sensitive plant" (erba viva in Italian), originally from the West Indies and first examined by the Portuguese natural historian Cristóbal Acosta (1515-94) in his Aromatum et medicamentorum in orientali India nascentium liber (Antwerpen: Christophe Platin, 1578), republished in an updated version by Charles de l'Écluse in his Exoticorum libri decem (1605).

142 This information about Thales was probably taken from Diogenes Laertius (Lives of Eminent Philosophers 1.1.24), who reports that Thales also considered inanimate beings to be endowed with a soul, founding his deduction on magnets and amber.

143 A highly influential book on magnetism, well-known by Paolo Sarpi and Galileo Galilei, was William Gilbert's De Magnete, Magneticisque Corporibus, et de Magno Magnete Tellure (On the Magnet and Magnetic Bodies, and on the Great Magnet the Earth) (London: Peter Short, 1600). The main theory he put forth was that the Earth was itself a giant lodestone and that this was the reason why compasses pointed north (previously, some

believed that it was the pole star or a magnetic island on the north pole that attracted the compass). 144 We have translated the vernacular verticità, corresponding to the English "verticity," common in the seventeenth century but now rare and obsolete, as "ability to turn."

145 The cubit was an old unit of length largely employed in antiquity, the Middle Ages, and in the early modern period, based on the length of a forearm.

146 Concerning the doctrine of mirrors, see the Euclidean Catoptrics (theorems 16, 17, and 18) and the work of the medieval philosopher Witelo (ca. 1220/30-77), Perspectiva, de elementatis conclusionibus (of which the first printed edition, entitled Optica, was published in Nuremberg in 1535).

147 This argument, meant to demonstrate that external objects do not give human beings and animals similar impressions, also occurs, with some slight differences, in Sextus Empiricus, Outlines of Scepticism 1.45.

148 The statement that external objects must be observed differently depending on the different constitutions of animals perceiving specific appearances is taken from Sextus Empiricus; see Outlines of Scepticism 1.55-58.

149 Luzzatto seems to be adopting the same argument developed by Sextus Empiricus at Outlines of Scepticism 1.112-18, and specifically: "Since, therefore, there are so many anomalies depending on conditions, and since at different times people come to be in different conditions, it is no doubt easy to say what each existing object appears to be like to each person, but not to say what it is like, since the anomalies are in fact undecidable."

150 Luzzatto is recalling the Latin proverb Sutor, ne ultra crepidam ("Shoemaker, not beyond the shoe"); see Pliny the Elder, Natural History 35.85. 
151 On plane mirrors, see Ptolemy, Optics 3.63-96.

152 Luzzatto seems to be referring to Democritus, who, according to Aulus Gellius (Attic Nights 10.17.12) blinded himself in order to free his mind from the distractions of sight and thus make his examination of Nature's laws more exact.

153 Luzzatto seems to be recalling here the position of praising the virtuous and peaceful Golden Age of humanity, to which the earliest reference is attested in Hesiod's Works and Days (109-26), or in Latin poetry in Ovid's Metamorphoses (1.5.101) and Virgil's Eclogues 4. Plato's account of this age (Statesman 271b-272b) is far from praiseworthy, as he denounced it for lacking political and social organisation and restricting human life to an animal and passive existence. The same criticism also occurs in Giordano Bruno's The Expulsion of the Triumphant Beast, where Jupiter, the spokesman for Bruno's opinion, delivers a speech against the commendation of the Golden Age made by the personification of Leisure and based on the famous passage from Lucretius's On the Nature of Things (5.925-1457) about man's liberation from an animal state. See Giordano Bruno, Lo Spaccio della Bestia Trionfante (London, 1584), chapter 3.

154 This statement is supported by the fifth common notion of book 1 of Euclid's Elements, namely that the whole is greater than the part.

155 On this topic of self-awareness, see footnotes 75 .

156 Lucretius, On the Nature of Things 1.426-8.

157 Dion (ca. 409-354 BCE) was a very influential philosopher during the tyrannies of Dionysius I and Dionysius II in Syracuse. He played a crucial role during Plato's journey to Sicily to the court of Dionysius I, where they first met. Dion was a disciple of Plato and the Pythagoreans. Although he was supportive of an aristocratic form of government, he became tyrant of Syracuse from 357 to 354 BCE. Plutarch portrays Dion in his Parallel Lives, comparing him to Brutus.

158 Archytas of Tarentum was a Pythagorean mathematician, philosopher, and political leader living in the first half of the fourth century BCE. He was a friend of Plato, probably from when the latter had been in Sicily in 338 BCE. Diogenes Laertius states that Archytas was the first to turn mechanics into a system by applying mathematical principles to it (Lives of Eminent Philosophers 8.4.83). Aristotle wrote more about Archytas's philosophy than about any other of his predecessors, but unfortunately almost nothing of these works has survived. Eudemus and Aristoxenus, Aristotle's disciples, examined Archytas's philosophy, the former in his history of geometry and in his work on physics and the latter in a Life of Archytas, a point of reference for his biographical tradition.

159 Luzzatto is here referring to the Aristotelian ten categories of being, which are the following: substance, quantity, quality, relatives, place, time, position, state, action, and affection (Categories 4.1b25-2a4). It is interesting to note that during late antiquity there was an attempt to render Archytas as an antecedent to Aristotle's theory of categories through a pseudoepigraphical work entitled Concerning the Ten Categories. Some ancient commentators on Aristotle were in fact deceived, effectively believing that the categories originally belonged to the Pythagorean tradition. See Thomas A. Szlezak, Pseudo-Archytas über Die Kategorien (Berlin: Walter De Gruyter, 1972).

160 Archytas was known to have built a dove made of wood which could fly. Aulus Gellius (Attic Nights 10.12.9-10) refers to this episode with polemical incredulity. Athanasius Kircher mentions Archytas's dove in his Ars magna lucis et umbrae (Rome: Grignani, 1646), book 10, part 2, 827-28.

161 We have translated the vernacular impennare, which literally means "to feather" in order to fly, as "rise to."

162 Dante, Purgatory 4.1-6.

163 Archelaus was a disciple of Anaxagoras and a probable teacher of Socrates. According to Diogenes Laertius, he was the last of the physical philosophers (Lives of Eminent Philosophers 2.16-17). He explained motion as an opposition of heat and cold originated by the will of a material Mind made of air. 164 We have decided to correct the vernacular esterni (literally "external things") to "extremities," because it is more consistent with the argument. 
165 On geometry, see the following works: Alessandro Piccolomini, Della sfera del mondo; De le stelle fisse (Venice: Al segno del Pozzo, 1540); Piccolomini, De la Instituzione di tutta la vita de l'omo nato nobile e in città libera (Venice: apud Hieronymum Scotum, 1545); Bonaventura Cavalieri, Geometria indivisibilibus continuorum nova quadam ratione promota (Bologna: Ferroni, 1635).

166 Luzzatto seems to be referring to squaring the circle, one of the classical problems of antiquity, together with angle trisection and doubling the cube, which were intensively debated until modern times and were also mentioned in poetry and literature (see, for example, Dante, Paradise 33.133-5). 167 On curiosity, see R. J. W. Evans and Alexander Marr, eds., Curiosity and Wonder from the Renaissance to the Enlightenment (Aldershot: Ashgate, 2006).

168 The epithet of "idle" (otiosi) addressed to lovers (amanti) recurred throughout Baroque literature and poetry; see, for example, Carlo Fiamma, Gelosa Ninfa, Favola pastorale (Venice: Roberto Meglietti, 1604), 64 and Alessandro Sperelli, Della Pretiosità della Limosina (Venice: Paolo Baglioni, 1666), 231. 169 The so-called "service of Venus" (militia Veneris) was a recurrent theme in Latin elegies, mostly expressions of the suffering occasioned by love, in which traditional military values were transposed into discussions of love. An example of this was Propertius, Elegies 4, 1.137: militiam Veneris blandis patiere sub armis ("You will suffer active service in the tender warfare of Venus").

170 These two verses are also quoted by Montaigne, Essays 2:11, 458.

171 Lucretius, On the Nature of Things 4.1106-11.

172 Luzzatto is referring to a traditional proposition of Galenic physiology, namely that the body's life and all its vital processes, such as digestion, the production of blood, the nourishment of body's organs, etc., depended on an innate heat; see Elisabeth Moreau, "Innate Heat," in Encyclopedia of Renaissance Philosophy online: https://link.springer.com/referenceworkentry/10.1007 \%2F978-3-31902848-4_399-1.

173 Chyle is a bodily fluid formed in the small intestine during the digestion of fatty foods. Luzzatto is referring to a very new discovery in early modern anatomical studies: the first study of the absorption of this fluid was published by the Italian physician Gaspare Aselli (1581-1625), who taught anatomy at the University of Pavia, in his De lactibus sive lacteis venis quarto vasorum meseraicarum genere novo invento (Milan: Giovanni Battista Bidelli, 1627); however, it was the French medical doctor Jean Pecquet (1622-74) who later discovered lymphatic circulation. See Experimenta nova anatomica. Ejusdem dissertation anatomica de circulation sanguinis et chyli motu (Paris: Sebastian et Gabriel Cremoisy, 1651).

174 Luzzatto is referring to Milo of Croton (sixth century BCE), a Greek wrestler who won six victories in the Olympiad, exactly like the peasant mentioned by Luzzatto. The same example also occurs in Montaigne, Essays 1:23, 156.

175 Lucretius, On the Nature of Things 5.534-9.

176 Luzzatto is here continuing the discussion about optics and the theory of vision started by Crito on pages $65-70$ of Socrates. Luzzatto returns to this topic by mentioning Galileo's telescope. This reference and the following discussion concerning physics and geometric aspects of vision prove that Luzzatto was keenly conscious that astronomical science depended on vision, as was highlighted by the discoveries of Kepler made shortly before the publication of Galileo's Sidereal Messenger. See Galileo Galilei, Sidereus Nuncius (Venice: Apud Thomam Baglionum, 1610). See also Paolo Mancosu, "Acoustics and Optics," in The Cambridge History of Science, eds. Katharine Park and Lorraine Daston, (Cambridge: Cambridge University Press, 2008): 3:613-14. On the impact of the new science on Jewish thinkers, see David B. Ruderman, Jewish Thought and Scientific Discovery in Early Modern Europe (New Haven-London: Yale University Press, 1995); Ariel Viterbo, "La mitzwah di studiare le scienze nell'opera di Rav Simchah (Simone) Luzzatto,” Segulat Israel 4 (1997): 54-67; Gianfranco Miletto, “Tradition and Innovation: Religion, Science, and Jewish Culture between the Sixteenth and Seventeenth Centuries," in Religious Confessions and the Sciences in the Sixteenth Century, ed. Jürgen Helm and Annette Winkelmann,(Leiden: Brill, 2001): 99-107; Jacob Adler, "Joseph Solomon Delmedigo: Student of Galileo, Teacher of Spinoza," Intellectual History Review 23, no. 1 (March 2013): 141-57; Adam Shear, 
"Science, Medicine, and Jewish Philosophy," in The Cambridge History of Judaism, ed. Jonathan Karp and Adam Sutcliffe (Cambridge: Cambridge University Press, 2017), 7:522-49.

177 This is the Aristotelian account of the Milky Way; see Aristotle, Meteorology 1.8.

178 Galileo put forth new evidence in favour of the Copernican theory, one portion of which was that Venus had phases like the moon. This discovery aided the further research which located Venus between the sun and the earth and stated that it revolved, like Mercury, around the sun and not around the earth; see Galilei, The Sidereal Messenger, 106-9 and 110-11, and Letters on Sunspots in Galilei, Istoria e Dimostrazioni intorno alle Macchie Solari (Rome: Accademia dei Lincei, 1613).

179 Galileo's further discoveries are the four planets circling Jupiter, which he called the Medicean stars after his patrons, the ruling family in Florence. This discovery strengthened the conviction that the lunar theory was incorrect and demoted the earth to one of the several existing planets; see Galilei, Sidereal Messenger, 110.

180 The rings around Saturn were observed for the first time by Galileo, although he did not identify them as rings, but instead believed that Saturn was made of three separate bodies; see Galilei, Sidereal Messenger, 102-3.

181 Mongibello was the ancient name for Mount Etna in Sicily and was used metaphorically in poetry and literature; see Ludovico Ariosto, Orlando Furioso 1.40.

182 In his Letters on Sunspots, Galileo showed that the sun was no longer perfect, but had spots and blemishes on its surface; see Galilei, Istoria e Dimostrazioni.

183 On the aforementioned emission theory of vision, see 66, footnote 131.

184 On the aforementioned Platonic account of vision, see 69, footnote 137.

185 On the aforementioned atomistic theory, see 66, footnote 132.

186 According to medieval optics based on the Galenic and Aristotelian theories of vision, there were three humours inside the eyes: the vitreous humour, the crystalline or glacial humour, which is like ice, and the albugineous humour. The glacial humour denoted the crystalline lens. Kepler, in the wake of the study by the Jesuit Christoph Scheiner (1573-1650) and contemporary anatomical research, highlighted the role of the crystalline lens in vision and the prime importance of the retinal organ; see Mancosu, "Acoustics and Optics," 616.

187 Luzzatto is referring to the projection of reversed images onto the retina, discovered by Christoph Scheiner during his research in Rome. He verified this phenomenon with anatomical dissections; see Mancosu, "Acoustics and Optics," 616.

188 According to the Stoics, vision works through a spirit or pneuma from the eyes that interacts with external light and detects the shapes of external bodies, establishing a cone which defines the visual field. On the Stoic theory of vision, see Samuel Sambursky, Physics of the Stoics (Princeton: Princeton University Press, 2014), 107-14.

189 Galen's theory of vision was very eclectic, pandering to Platonic, Aristotelian, and Stoic accounts, and he believed that perception was made possible thanks to a "spirit" circulating through the crystalline lens. This spirit could collect information from the outside world and bring it back into the optic nerves to the brain; see Roland Betancourt, Sight, Touch, and Imagination in Byzantium (Cambridge: Cambridge University Press, 2018): 54-63; Katerina Ierodiakonou, “On Galen’s Theory of Vision,” in Philosophical Themes in Galen (BICS supplement, 114), eds. Peter Adamson, Rotraud Hansberger, and James Wilberding (London: Institute of Classical Studies, School of Advanced Study, University of London, 2014), 235-47.

190 Through this statement, Luzzatto shows that he is targeting the classical central sceptical claim, namely that appearances do not reveal to us the true nature of reality itself.

191 The same argument may be found in Sextus Empiricus, Outlines of Scepticism 1.40-44.

192 The same reference to the nightingale's harmonious singing occurs in Montaigne, Essays 2:12, 490.

193 Many passages of Sextus Empiricus's Outlines of Scepticism are devoted to the relativity of perception; see specifically 1.94; 135; 140. 
194 "Panderism" or "procuring," from the original arte lenonia, defined by Ulpian as the keeping of free women for prostitution or slaves and the profits from this. See Henry Cornelius Agrippa, The Vanity of Arts and Sciences, (London: Samuel Speed, 1676), chap. 64: “Of Pandarism, or Procuring” (De arte lenonia). 195 Aristotle discussed the nature of light and colours in his On the Soul and On Sense and Sensible Objects and devoted a part of Meteorology to rainbows (3.2) and the halo, showing his knowledge of refraction.

196 In optics, the phenomenon of diffraction, which splits light by means of a triangular prism, was studied by both scientists and alchemists. Luzzatto seems to waver between a scientific approach to this topic and alchemistic studies. It is necessary to point out that they only began to differ from one another in the sixteenth century. Luzzatto may be referring to the work of Athanasius Kircher, Ars Magna Lucis et Umbrae, published in 1646. For the development of scientific theories about optics and light from the sixteenth century until Newton's discoveries, see Mancosu, "Acoustics and Optics," 613-31.

197 The example of the dove's neck occurs in Sextus Empiricus; see Outlines of Scepticism 1.120, where he describes how the same object looks different depending on its positions.

198 Luzzatto seems to be repeating the theory of colours and reflection discussed by Aristotle in his Meteorology 3.2-3, On the Soul 2.7, and On Sense and Sensible Objects $(3,6,7)$ in this passage.

199 Callicles was the interlocutor of Socrates in the Platonic dialogue Gorgias. He was a promoter of the contemptuous argument that the weak members of society should accept being dominated and oppressed by strong individuals.

200 Virgil, Aeneid 6.272.

201 The miser obsessed with his wealth became a character in Molière's The Miser (1668), drawn from Plautus's Latin play The Pot of Gold (Aulularia). He was also depicted by Theophrastus in his work Characters (30, Chiseling). On Theophrastus's Characters and Luzzatto, see Giuseppe Veltri, “'Dannare l'universale per il particolare?' Colpa individuale e pena collettiva nel pensiero di Rabbi Simone Luzzatto," Rassegna mensile di Israel 77 (2012): 74-75.

202 Critias (ca. 460-403 BCE) was a pupil of Socrates and a leading member of the oppressive oligarchic government of the Thirty Tyrants, who ruled Athens after it was defeated in the Peloponnesian War in $404 \mathrm{BCE}$.

203 A referendary was an official in papal, imperial, and some royal courts who had the task of examining and reporting on requests, petitions, and other matters. This definition of imagination also occurs in Socrates, 118-19. See also Ariel Viterbo, "Socrate nel ghetto," 96.

204 According to Avicenna's interpretation of Aristotle's On the Soul, there are five internal senses: common sense, imagination, cogitative sense, estimative sense, and memory. Avicenna was the first to conceive the faculty of estimation (Lat. aestimatio), which was intended to explain the animal and human capacity to perceive non-sensible intentions presented to them by an object during perception. See Deborah L. Black, "Estimation (Wahm) in Avicenna: The Logical and Psychological Dimensions," Dialogue 32, no. 2 (Spring 1993): 219-58; Black, "Imagination and Estimation: Arabic Paradigms and Western Transformations," Topoi 19, no. 1 (April 2000): 59-75.

205 Manilius, Astronomica 4.108-16.

206 Medea is known as a sorceress in many mythological stories. Together with Jason, she was one of the main characters in Apollonius of Rhodes's Argonautica, which was a source of inspiration in both Greek and Latin literature. In Euripides's play Medea, she is a controversial character, avenging Jason's abandonment of her by murdering their children. Ovid's Metamorphoses, which is Luzzatto's source here, presents a different Medea, wavering between rationality and passionate desires.

207 Ovid, Metamorphoses 7.19-21.

208 Ovid, 7.17-18.

209 On common sense, see Aristotle, On the Soul 3.2; Memory and Reminiscence 1. "Common sense" becomes a technical term in later commentators on Aristotle; see Victor Caston, "Aristotle on Consciousness," Mind 111, no. 444 (October 2002): 800-804; Pavel Gregoric, Aristotle on the Common Sense (Oxford: Oxford University Press, 2007). 
210 This analogy of common sense with the centre of a circle in which infinite lines converge is drawn from Alexander of Aphrodisias's On the Soul. Alexander of Aphrodisias, Praeter commentaria scripta minora: De anima liber cum Mantissa, ed. Ivo Bruns (Berlin: Reimer 1887), 63.12-13. Alexander's innovation was inspired by Aristotle's analogy of common sense with a point bisecting a line in On the Soul 3.2.427a9-14.

211 Although anatomical examinations were not completely unknown among the Greeks, nevertheless Luzzatto seems to be referring to the scientific progress in anatomy made during the sixteenth and seventeenth centuries. On this account, see Jacalyn Duffin, A History of Medicine: A Scandalously Short Introduction, 2nd ed. (Toronto: University of Toronto Press, 2010), especially the chapter "The Fabricated Body: History of Anatomy"; Jacques Le Goff and Jean-Charles Sournia, Per una storia delle malattie (Bari: Edizioni Dedalo, 1986), especially Pierre Darmon, "Il furto dei cadaveri e la scienza nei secoli XVII-XIX”, 93-109.

212 The idea that "perception requires likeness" between the compositions of the subject and the object was attributed to Empedocles's theory of knowledge, afterwards taken up by Aristotle; see Aristotle, On the Soul 1.2.404b12-15 and Metaphysics 3.4.1000b5-8. Aristotle's quotation of Empedocles's famous fragment occurs in Socrates, 187.

213 On the category of relatives, see Aristotle, Categories 4.1b25-2a4. Luzzatto also discusses this category in Socrates, 17; 31-33; 43-44; 122; 162-63; 229.

214 Antisthenes (ca. 445 - ca. 365 BCE), according to Diogenes Laertius (Lives of Eminent Philosophers 6.1.1-2), was originally a pupil of Gorgias and then became one of the most important followers of Socrates and the founder of the Cynic school. According to Aristotle (Metaphysics 8.3), he took a nominalist approach towards the problem of universals in logic: thanks to Simplicius, his disbelief in the Platonic theory of ideas, in which he uttered that he could see a horse, but not "horseness," became famous. Simplicius, On Aristotle Categories 7-8, tr. Barrie Fleet (London: Bloomsbury, 2014), 208.28.

215 Luzzatto's source could be Thomas Aquinas, Commentary on Peter Lombard's First Book of the Sentences, related to Paulus Venetus, article 2: “are all sins equal?” In the Solution, he refers to the third paradox discussed by Cicero in his Stoic Paradoxes, who stated that all transgressions were equal.

216 The parasang was an antique unit of length used throughout the Middle East and also known in Greece. It is not easy to define this measurement using the metric system: several Greek and Roman writers, such as Herodotus (Histories 2.6; 5. 53; 6.42), Xenophanes (Anabasis 2.2.1), Pliny the Elder (Natural History 6.26), and Strabo (Geography 7) mentioned it, assigning it different lengths. This measurement is also mentioned in the Babylonian Talmud, in which it is upheld that a person can walk ten parsot (parasangs) a day, namely $44.45 \mathrm{~km}$ (see bPesachim 93b).

217 Cleinias (fourth century BCE) was a Pythagorean philosopher and friend of Plato (see Diogenes Laertius, Lives of Eminent Philosophers 9.40).

218 Aristarchus of Samothrace (ca. 220-ca. 143 BCE) was the librarian of the library of Alexandria, a well-known grammarian, and a scholar of Homeric poetry.

219 Agathon (ca. 445-401 BCE) was a tragic poet. He won his first prize in the dramatic competition at the Lenaia in 416 BCE. He is also one of the characters of Plato's Symposium, held to celebrate his victory.

220 According to Avicenna, the internal senses were located in three ventricles of the brain, two in each ventricle; see Black, "Imagination and Estimation," 59-60.

221 According to Aristotle, who considered the heart connected to all the sensory organs; see Aristotle, On Youth and Old Age 468b17-469a24.

222 See Avicenna, On the Soul 1.5 and 4.1.

223 Imagination in Aristotle was essentially the mind's reception of images or phantasmata. According to him, through perception, an image was imprinted upon the mind in the same way a signet imprints its seal upon wax; see On the Soul 2.12, Memory and Reminiscence 450a25-451a19.

224 On this topic, see Socrates, 67. 
225 The vernacular commotione (from Latin commotio) has been translated as "alteration." Commotione was a general term adopted to designate the emotions as motions and alterations of the humours or spirits when the soul was affected, but also as perturbations of the body. The reference to passions as perturbations implies Luzzatto's acceptance, like many other early modern authors, of the neo-Stoic sense of passion as a force acting upon the body; see Bernardino Fantini, "The Historical Development of the Dictionaries of Emotions," in Storia della Scienza e linguistica computazionale, ed. Liborio Dibattista (Milan: Francoangeli, 2009): 15-33.

226 See also Socrates, 57-59.

227 We have translated the vernacular risentimento as "affection," which also occurs in Luzzatto, Discourse 6r.

228 On the analogy of the referendary, see Socrates, 106 and footnote 203.

229 Euclid of Megara (ca. 435-ca. 365 BCE) was the founder of the Megarian school of philosophy. He was a pupil of Socrates and present at his death. Interested in logic, he would argue following the reductio ad absurdum, and according to Diogenes Laertius (Lives of Eminent Philosophers 2.10.107), he rejected argument by analogy.

230 Heteroclite (Latin heteroclitus) means "exceptional, abnormal, odd."

231 Ovid, Metamorphoses 9.469-71.

232 On dreams, see Dreams, Dreamers, and Visions: The Early Modern Atlantic World, ed. Ann Marie Plane and Leslie Tuttle (Philadelphia: University of Pennsylvania Press, 2013); specifically in the Jewish tradition, see Hagar Kahana-Smilansky, "The Mental Faculties and the Psychology of Sleep and Dreams," in Science in the Medieval Jewish Cultures: A State of the Art, ed. Gad Freudenthal (New York: Cambridge University Press, 2011), 230-54; Annalies Kuyt, "Dreams - Who, What, When and Why? Shlomo Almoli on the Meaning of Dreams," Frankfurter Judaistische Beiträge 36 (2010): 95-111.

233 See Socrates, 116, footnote 225.

234 There was much debate on human memory and techniques for improving it during the seventeenth century, including among the Jews. An example of this was the small book on this topic published in Hebrew in 1612 by Leon Modena entitled Lev Aryeh, where he dealt with the so-called "local memory" (see also Socrates, 127-28), which appeared in the classical tradition and was then also debated during the Middle Ages and Renaissance. Luzzatto is referring to this method and mocking it. See Ariel Vieterbo, "Socrate nel ghetto," 97; Giuseppe Sermoneta, "Aspetti del pensiero moderno nell'ebraismo italiano tra Rinascimento e età barocca," Italia Judaica 2 (1986): 17-35; Lina Bolzoni, La stanza della memoria: Modelli letterari e iconografici nell'età della stampa (Turin: Einaudi, 1995); Frances A. Yates, The Art of Memory (London: Routledge and Keegan Paul, 1966).

235 We have translated the vernacular refertissima (from the Latin refercio) as "filled with."

236 On the immortality of the soul, see Plato, Phaedo.

237 We have translated the vernacular massaio, which formerly addressed the charge of an official responsible for guarding the public treasury, collecting taxes, and administrating finances, as "custodian.”

238 The decision to translate the word cavaliere (literally, "knight") as "judge" is due to the role of the knights, who were officers with judicial functions.

239 This sentence seems to be alluding to the Latin phrase Sed quis custodiet ipsos custodes? ("Who will guard the guards themselves?") from Juvenal's Satires (6.347-48) concerning the issue of controlling those who occupy a position of power, but most of all, it is an example of the Sceptic's use of an infinite regress argument; see Sextus Empiricus, Outlines of Scepticism 1.122, 166, 168, 171, 172, 176, 179, 186; 2.20, 36, 40, 78, 85, 89, 90, 92, 93, 182, 207-8; 3.8, 24, 36, 44, 53, 67, 68, 76, 162, 241.

240 Plato, Timaeus 48e-50c. The passage discusses a third principle next to those of Model and Copy, which is necessary for the formation of the World; the Forms require a permanent substrate, formless but capable of receiving every kind of form, upon which they may imprint themselves.

241 Lucretius, On the Nature of Things 3.935-38. 
242 Protarchus was one of the protagonists of the Platonic dialogue Philebus, which concerns the relative value of knowledge and pleasure.

243 Luzzatto is referring to the mnemonic technique known as the method of loci. See Cicero, On the Orator 2.86.

244 On the theory of natural place, see Aristotle, On the Heavens 1.8.

245 On projectile motion, see Aristotle, Physics 4.8.215a2-b23.

246 Boethius, The Consolation of Philosophy 3 m. 2.27-30.

247 This reference to anatomical dissection demonstrates that Luzzatto was up-to-date with the anatomical studies of the time, made possible thanks to pioneering autopsies and the critical examination of Galenic works led by the university of Padua during the sixteenth and seventeenth centuries; see Andreas Vesalius (1514-64) and his Tabulae Anatomicae (Venice, 1538) and De humani corporis fabrica (Venice, 1543), and the works of Girolamo Fabrizio dell'Acquapendente (1533-1613).

248 Luzzatto seems to be referring to Critias's opinion; see Aristotle, On the Soul 1.2.405b5-10.

249 This is a reference to the Stoic position.

250 Virgil, Georgics 4.219-21.

251 Luzzatto seems to be referring to Aristotle's concept of passive or potential intellect (On the Soul 3.5.430a10-25).

252 See Plato, Phaedrus 246a-b.

253 See Giordano Bruno, Causa, principio et uno (Venezia: s.n., 1584); English translation in Cause, Principle and Unity and Essays on Magic, ed. Richard J. Blackwell and Robert de Lucca with an introduction by Alfonso Ingegno (Cambridge: Cambridge University Press, 1998), second dialogue.

254 This is a reference to Thales; see Aristotle, On the Soul 1.2.405a20-22.

255 Luzzatto is here referring to the Pythagorean and Platonic opinions.

256 Virgil, Aeneid 5.700-702.

257 Proteus was Poseidon's son according to Greek mythology. He had some typical characteristics of the marine deity: old age, the gift of prophecy, and the ability to assume many different shapes.

258 This passage recalls Sextus Empiricus's fifth trope on positions, intervals, and places; see Outlines of Scepticism 1.118-23.

259 Virgil, Aeneid 3.72. This verse is also quoted by Montaigne 2:13, 632.

260 Terence, The Eunuch 1.1.1-4.

261 This opinion is taken from the Stoic and Galenist notions of animals' spirits, namely that virtues are animals (virtutes esse animalia) in the human soul, delivered by Seneca's Epistles 93. See Giuseppe Veltri, "Dannare l'universale per il particolare," 72-73. The same belief also occurs in Descartes's Passions of the Soul (1649).

262 Luzzatto seems to be referring to his earlier book, the Discourse, where the same belief occurs in consideration XI: "Referring to the Difficulties in Describing the Customs of the Jews in General," $35 \mathrm{v}-36 \mathrm{r}$.

263 Luzzatto is referring to the ancient myth of Saturn, who devoured his children.

264 A seraglio or serail was a containment wall used, for example, as a cage for wild animals. In 1555, following the papal bull Cum nimis absurdum, the ghettos established in Italy were originally called serraglio degli ebrei ("enclosure for the Jews"). See Sandra Debenedetti-Stow, "The Etymology of 'Ghetto': New Evidence from Rome," Jewish History 6, no. 1-2 (1992): 79-85.

265 Alcibiades was a famous general, statesman, and orator. He played a crucial role in the second half of the Peloponnesian War as a military advisor. He was a greatly controversial figure in ancient Greece, as on the one hand he was criticised for his extreme ambition (see Thucydides, The History of Peloponnesian War 6.15) and on the other he was praised for his brilliant wit and great endeavours and achievements (see Diodorus, Library 13.68.5). He was known for his close relationship with Socrates, whom he admired (see Plato, Symposium).

266 On the concept of right reason (recta ratio), see Thomas Aquinas, Commentary on Aristotle's Ethics, book 7, where he argues that incontinent people do not follow right reason. The court of the Inqui- 
sition grounded its proceedings on this ethical foundation, considering itself to be the custodian of recta ratio and thus to have the ability to correct those who were mistaken.

267 Euripus is the strait separating the island of Euboea from ancient Boeotia in mainland Greece and is subject to strong tidal currents; thus, it became a well-known image for indicating a person's unstable character. In Plato's Phaedo, Socrates refers to the imagery of Euripus's tide as a metaphor for the state of confusion experienced by those who are unable to choose between opposites; see Plato, Phaedo 90c.

268 See Plato, Republic 4.436a-b; Phaedrus 246a-254e.

269 See Plato, Timaeus 73b.

270 Virgil, Aeneid 8.564-66

271 Ovid, Art of Love 1.3-4

272 In this passage, Luzzatto is recalling the subheading of Socrates, which states: "How Deficient Human Understanding Can Be When It Is Not Led by Divine Revelation.”

273 See Aristotle, On the Soul 3.5.430a10-25.

274 The image of an oyster bound to its shell as a symbol of the soul's relationship to the body was originally adopted by Plato (Phaedrus 250c) and then taken up, with some variations, among Stoic, Neoplatonic, and early Christian thinkers.

275 Boethius, Consolation of Philosophy 5 m. 4.1-9.

276 Luzzatto has already discussed the mind's reflective faculty on page 29; see footnote 75 . See Marsilio Ficino, Platonic Theology 10.5.

277 Boethius, Consolation of Philosophy 5 m. 4.10-29. Verses 13 and 16 are missing from Luzzatto's quotation, and the translation was slightly revised accordingly.

278 The topic of hermaphroditism is present both in the Greek and Latin traditions (Hesiod, Theogony 203-206; Ovid, Metamorphoses 4; Plato, Symposium 190c-192d) and in the Jewish tradition (Talmud Bavli, Baba Batra 140a-b).

279 Luzzatto is combining two Aristotelian notions; in Aristotelian biology, the passive element in reproduction is identified with the female gender, and the active element is identified with the male (see for example Generation of Animals 1.729b5-20). Within the discussion of the intellect, Aristotle introduces the idea that there is both a passive and an active intellect in every human being (see On the Soul 3.4-8). These ideas were developed considerably during late antiquity and the middle ages. See for example Thomas Aquinas, Commentary on Aristotle's De Anima, trans. Kenelm Foster and Sylvester Humphries (New Haven: Yale University Press, 1951), 3,5, lectio 10.

280 Luzzatto is using rabbinical language in speaking of these dogmata: according to rabbinic literature, the țumțum, being a hermaphrodite, has the disadvantages of both females and males. See Giuseppe Veltri, Eine Tora für den König Talmai: Untersuchungen zum Übersetzungsverständnis in der jüdisch-hellenistischen und rabbinischen Literatur (Tübingen: Mohr, 1994), 45-46.

281 On this topic see Giuseppe Veltri, Sapienza alienata. La Filosofia ebraica tra mito, storia e scetticismo (Ariccia: Aracne, 2017), 251-260.

282 Luzzatto is here debating the topic of common sensibles presented by Aristotle in On the Soul 3.1.425a-b10.

283 Thanks to the significant role played by the study of optics accomplished by Alhazen's De Aspectibus, a new school based on his teaching, the Perspectivists, was founded during the thirteenth century. The founders were Roger Bacon in On the Science of Perspective (which was part of his Opus Majus, 1267-68) and De multiplicatione specierum, Witelo in Perspectiva (incorporated into Optica Thesaurus, 1572) and John Peckham in Perspectiva Communis (written around 1270).

284 See Regiomontanus, De Triangulis (1533), which was considered as the foundation of modern trigonometry and opened the way to the construction of trigonometrical tables of ever greater precision. Regiomontanus's work was continued by Georgius Rhaeticus (1514-67) and Valentin Otto (1550-1605), and reached its peak with Pitiscus (1551-1613).

285 See Alhazen, Book of Optics (De Aspectibus), based on Galen's doctrine, in which glacial humours are primarily responsible for the eyesight; see The Optics of Ibn al-Haytham. Books I-III: On Direct Vision, trans. Abdelhamid I. Sabra, 2 vols. (London: Warburg Institute, 1989). 
286 We have translated the original rimbambire as "foolish"; Luzzatto is playing on its ancient etymological meaning of returning to a childlike state and thus being naïve and not corrupted by custom. Luzzatto may have had in mind the pseudo-Hippocratic letters exchanged with the Abderites, who were convinced that Democritus was in need of medical treatment. The main signs of Democritus's insanity were his irrepressible laughter directed at human life and customs and his bizarre theories. Yet Hippocrates's diagnosis was rather that Democritus suffered from high wisdom, which was not an illness, but was perceived as such by most people. See George Kazantzidis, "Between Insanity and Wisdom: Perceptions of Melancholy in the Ps.-Hippocratic Letters 10-17," in Mental Illness in Ancient Medicine: From Celsus to Paul of Aegina, ed. Chiara Thumiger and P. N. Singer (Leiden: Brill, 2018), 42-44.

287 It must be noted that most of the following opinions that Luzzatto lists belong to the long-running debate on the soul.

288 The dispute about the precise location of the ruling part or intellect in the body had already occurred in Sextus Empiricus; see Outlines of Scepticism 1.126; 2.32, 58, 70-71, 81; 3.169, 188; Against the Mathematicians 7.313; 9.119. The complete account on this issue is in Galen, On the Doctrines of Hippocrates and Plato, ed. and trans. Philip De Lacy (Berlin: Akademie-Verlag, 1981), 2-3. See Julia Annas, Hellenistic Philosophy of Mind (Berkeley: University of California Press, 1992), chapter 2.

289 This was the Stoic position. The same reference occurs in Montaigne, Essays 2:12, 570.

290 Montaigne ascribed this account to Hippocrates and the Greek physician and anatomist Herophilus (335-280 BCE); see Essays 2:12, 569.

291 This was the opinion of Erasistratus (ca. 304-ca. 250 BCE), who was a Greek anatomist and, with Herophilus, the founder of the Alexandrian school of anatomy; see Montaigne, Essays 2:12, 570.

292 According to Montaigne, this was Strato's view; see Essays 2:12, 570.

293 See a reference to this idea (and its rejection) in Aristotle, Parts of Animals 3.10.

294 This was Epicurus's account; see Lucretius, On the Nature of Things 3.102; 142. It also occurs in Montaigne's Essays (see 2:12, 569).

295 We have translated the vernacular esquisito as "typical” following the Oxford English Dictionary, which refers to the Greek akribēs, rendered as exquisitus in the Latin versions of Galen.

296 This was Hippocrates's account, which is also mentioned by Montaigne; see Essays 2:12, 569.

297 This was Aristotle and Democritus's view; see also Montaigne, Essays 2:12, 569.

298 This was Varro's opinion on the essence of the soul; see Essays 2:12, 1665.

299 We have not yet located the source of this reference.

300 Divisible and indivisible time were concepts discussed by some Italian scholars during the Renaissance such as Marcantonio Genua (1491-1563), Giulio Castellani (1528-86), Antonio Montecatini (1537-99), and Francesco Piccolomini (1520-1604), who were significantly influenced by the Simplician and Alexandrist interpretations of Aristotle's works. They suggested an alternative point of view based on the interpretation of On the Soul 3.6.430b7-20, which stated that intellectual acts occur in both "divisible" and "indivisible time." See Olivier Dubouclez, "On the Time of the Intellect: The Interpretation of De Anima 3.6 (430b7-20) in Renaissance and Early Modern Italian Philosophy," Early Science and Medicine 20 (2015): 1-26.

301 On right reason, see Socrates, 138, footnote 266.

302 Luzzatto's explanation is confusing, but the five aspects he seems to enumerate are light, colour, dimensions, position, and time. For the perspectivists, see above, Socrates, footnote 283.

303 Mayflies were described in antiquity by Pliny the Elder (Natural History 11.43).

304 The problem of universals emerges from the question of whether properties exist in reality or merely in thought and speech. There were different philosophical accounts of them: in ancient times, the Platonic and Aristotelian realisms claimed that universals had real existence as universalia ante res according to Plato and universalia in rebus according to Aristotle. Nevertheless, the problem of universals cannot be addressed without considering the long debate about them developed by Scholastic philosophy during the Middle Ages through the arguments of Duns Scotus, Thomas Aquinas, Peter 
Abelard, William Ockham, etc., which was originated by Boethius's terminology used for the Latin translation of Porphyry's Isagoge.

305 Luzzatto seems to be referring to the abstractions discussed within the framework of Abelard's moderate realism concerning the problem of universals. However, the issue also was taken into account by al-Fārābī in his Epistle on the Intellect and Averroes in his Long Commentary the De Anima of Aristotle, ed. and trans. Richard C. Taylor (New Haven/London: Yale University Press, 2009), 310-15, 349-52, 416-18.

306 Luzzatto seems to be playing with the word "particular" in juxtaposition with "universal."

307 By maximists and formalists Luzzatto meant here those who are indifferent to the individuality of each case and assess only according to general maxims or remain blidly stuck to the rules.

308 We have translated the original retto discorso, which Luzzatto used interchangeably with retta ragione, as "right reason." On this concept, see Socrates, 138, footnote 266.

309 The concept of "asininity" recurred throughout Giordano Bruno's writings. He described the scholarly world of his time as "pedant asses" (asini pedanti) with "asininity" (asinità) as their main characteristic, which summarised the stubborn stupidity of their egos and the simplicity of their ignorance; see Nuccio Ordine, Giordano Bruno and the Philosophy of the Ass, trans. Henryk Barański (New Haven: Yale University Press, 1996).

310 Horace, Epistles 1.42.

311 Luzzatto perhaps had in mind Proverbs 16:16: "How much better is it to get wisdom than gold" (קנה חכמה מה טוב מחרוץ). The Clementine Vulgate version is posside sapientiam, quia auro melior est.

312 On the principle of non-contradiction, see Aristotle, Metaphysics 4.3.1005b19-20.

313 Luzzatto may have taken the image of floating castles from Ludovico Ariosto's Orlando Furioso (12.1-37), with which he was very conversant. A reference to Orlando Furioso also occurs in Socrates, 172. Concerning the dualism of reality and appearance, see Montaigne's Essays (2:6, 411), where the Montaigne recalls our capacity to build "castles in the air" with our imagination.

314 On this geometrical issue, see rabbi Moshe Provenzali, Opera nova di geometria (Mantova: Ad instantia de Iacomo di Ruffinelli, 1550).

315 Here, there is a change to direct discourse, and Socrates is the speaker.

316 Literally, "singularity."

317 Luzzatto seems to be referring to Euclid, Elements, book 7, definition 1.

318 On the correlatives, see Aristotle, Categories 7.6b37-7a21.

319 Anacharsis the Scythian was the first foreigner to receive the privileges of Athenian citizenship and, according to some authors (see Diogenes Laertius, Lives of Eminent Philosophers 1.8), he was deemed one of the Seven Sages of Greece. He was considered a precursor of the Cynic school of philosophy.

320 Luzzatto is referring to the Stoic doctrine of animal spirits defended in his Discourse (35v); see Socrates, 137-38, footnote 261.

321 We have translated the vernacular verticità as "ability to turn"; see footnote 144.

322 Diogenes of Sinope (ca. 412/403-ca. 324/321 BCE) was known as the Cynic. Many tales described his simple lifestyle and extravagant behaviour, which expressed his criticism of the conventional social values of the city.

323 The expression homo homini Deus ("a man is a god to another man") comes from Caecilius Statius (quoted by Symmachus, Epistles 9.114). Homo homini lupus ("a man is a wolf to another man") is mentioned by Plautus (The Comedy of Asses 1.4.89). The third one, homo homini homo ("a man is a man to another man"), is from Francisco de Vitoria, De Indis, in Relectiones XII Theologicae (Lyon: Petri Landy, 1583), vol. 1.

324 In ancient Rome, a fetial was a priest who carried out the duty of informing the senate of foreign affairs, as well as that of formally proclaiming a state of peace or war.

325 In the Middle Ages, a herald was a noble who was charged with attending tournaments on the king's behalf, with proclamations of war or surrender, and with confirming peace treaties. 
326 Ludovico Ariosto, Orlando Furioso 10.7. The same quotation also appears in Montaigne's Essays $(1: 28,228)$.

327 According to the Stoic tradition, there is a cosmic spirit that holds the universe together by permeating it and giving a kind of life to all forms.

328 The reference here is to the Aristotelian concept of the "unmoved mover" as the first uncaused cause, which is not originated or moved by any prior action (see Physics 8).

329 Francesco Patrizi was a supporter of an animistic interpretation of the stars, which, according to him, were alive and not fixed in the heavens; see Nova de universis philosophia (Ferrara: Benedicti Mammarelli, 1591; also printed in Venice in 1593).

330 This was the opinion of Tycho Brahe, who believed that the stars were fixed in the heavens like knots in a board (sicut nodi in tabula); see De mundi aetherei recentioribus phaenomenis (1603).

331 Luzzatto is here referring to the heliocentric model of Aristarchus of Samos, which was not universally accepted until the Copernican Revolution.

332 Prodicus (ca. 465 BCE - ca. 395 BCE) was a sophist and highly esteemed by Plato, who often mentioned him in his dialogues, where he appeared to be a friend of Socrates. In religion, he interpreted "deity" in a naturalistic sense and was devoted to linguistics and ethics. The content of one of his speeches, in which Heracles, still young, has to make a choice between a life of virtues or of vices (see Xenophon, Memorabilia 2.1.21), is very famous.

333 The mina was an ancient Near Eastern unit of weight.

334 Parian marble was a very refined kind of marble, known to be pure white and flawless; there were quarries for it on the Greek island of Paros.

335 Luzzatto is quoting Thomas Aquinas, Summa Theologica, 2.2, Q 22, art. 1; Commentary on Aristotle's De Anima 3.4, lectio 9, 720; Quaestiones disputatae de Anima, art. 6, obj. 5, the solutio: intelligere est quoddam pati, and a little further on, intelligere pati est, ut dicitur in 3 De Anima. Originally, Aristotle wrote: "Thinking, both speculative and practical, is regarded as a form of perceiving" (On the Soul 3.3.427a20-21).

336 See Aristotle, On the Soul 3.5.

337 In our translation we have corrected Luzzatto's error in the numerical sequence.

338 Although Socrates states that he does not agree with the Platonic doctrine, nevertheless, he cannot hide his sympathy for it, which is evident from the names with which he addresses Plato's followers, namely as "more cheerful people" and on page 183 as those advocating a "playful opinion." 339 See Plato, Timaeus 90a-b

340 Luzzatto is here recalling the concept of anima mundi, a concept developed into cosmological doctrine by Plato in his Timaeus (30b-c; 33b). The idea of anima mundi became a topos within Renaissance culture, which was acquainted with Platonic and Neoplatonic texts through Marsilio Ficino's translations, whereof Theologia platonica provided a synthesis and introduction to the entire Platonic tradition; see Tullio Gregory, “Anima del mondo," Bruniana \& Campanelliana 12, no. 2 (2006): 525-35. 341 The sun.

342 Virgil, Aeneid 6.724-28.

343 Luzzatto is explicitly referring to having gathered the well-known image of Lethe as the river of oblivion from Virgil (Aeneid 6.714-15) and in medieval literature from Dante's Divine Comedy (Purgatory 28).

344 See Plato, Meno 80d-86c; Phaedo 72e-78b.

345 On the meaning of "instance," see Socrates, 9, footnote 19.

346 The runaway slave was a metaphor for the impossibility of new knowledge in favour of a recollection of past knowledge: either we know something already, or we do not. If we do, there is no point in the search. If we do not, it is not possible to seek something of which we have no knowledge. See Plato, Meno 97d-e, Cicero, The Speech on Behalf of King Deiotarus (45) 1.3, and Erasmus of Rotterdam, Adages 1262, 2.3.62. 
347 We have translated the vernacular animo as "soul," because in this case (from p. 183 to p. 185) it is more consistent with the Platonic theory of recollection to which Luzzatto is referring. However, it must be underlined that in Plato's philosophy, the functions of the soul are not restricted to desire and emotion, but also include cognition.

348 On the idea of anima mundi, see Socrates 180 footnote 340.

349 Luzzatto is referring to the Platonic idea that our soul is a fragment of the anima mundi; see Plato, Timaeus 37b-c.

350 Phaedo (fourth century BCE) was sold into slavery and then met Socrates, who freed him, in Athens. From there onwards, he devoted himself to philosophy, and Plato named his dialogue Phaedo, in which the immortality of the soul is discussed, after him.

351 Daedalus's statues were known for being such perfect copies of their real models that they were reputed to be able to walk and run away if they were not tied down. Thanks to their ambiguity of being between lifeless and living bodies, they became a commonplace from ancient until early modern literature, not only in dramas and comedies, but also in philosophy. In this respect, see Plato, Meno 97c4-98a3 and Euthyphro 11b-e. They are also referenced by Erasmus of Rotterdam's Adages (1262, 2.3.62). Comparison to Daedalus's statues was a topos in many panegyrics to engineers in the early modern era and was also known in Jewish circles; see Daniel Jütte, Das Zeitalter des Geheimnisses: Juden, Christen und die Ökonomie des Geheimen (1400-1800) (Göttingen: Vandenhoeck \& Ruprecht, 2011), 306-13.

352 See Plato, Meno 97d-e: "Socrates: It is because you have not observed with attention the images of Daedalus. But perhaps there are none in your country. Meno: What is the point of your remark? Socrates: That if they are not fastened up they play truant and run away; but, if fastened, they stay where they are. Meno: Well, what of that? Socrates: To possess one of his works which is let loose does not count for much in value; it will not stay with you any more than a runaway slave: but when fastened up it is worth a great deal, for his productions are very fine things and to what am I referring in all this? To true opinions."

353 The Gordian knot was famous for joining the yoke of a Phrygian wagon to a pole in the acropolis of the city of Gordium, and a local legend established that whoever managed to loosen the knot would acquire control of the whole of Asia. It is recalled that in 333 BCE, Alexander the Great could also not untie the knot, and therefore that he cut it with his sword. See Arrian, Anabasis of Alexander 2.3; Quintus Curtius Rufus, Histories of Alexander 3.1.14.

354 Dionysodorus was a sophist who, with his brother Euthydemus, appeared in Plato's dialogue Euthydemus, where Plato satirised the eristic method of argument.

355 See Aristotle, On the Soul 1.2.404b14-16, also quoted by Sextus Empiricus in Against the Logicians 1.121 and in Erasmus of Rotterdam's Adages 120.1.2.20.

356 Cyrus II of Persia (600-530 BCE) was known as Cyrus the Great, founder of the first Persian empire. Cyrus was praised by the Jews, as is attested by some biblical passages (see Isaiah 40-55), for having freed the nation of Israel from exile without requesting any tribute.

357 Plautus, The Two Menaechmuses, Prologus 18-20.

358 Ixion was king of the Lapiths in Thessaly, guilty of having murdered his father-in-law and having shown ingratitude to Zeus, who pitied him. His punishment was to be bound to a winged fiery wheel that was constantly spinning.

359 We have translated the vernacular calmistrato (Latin calmister was the tool used to curl hair), which literally means "to curl one's hair in order to become more attractive," as "embellished." See Ovidio Montalbani, Vocabolista Bolognese, nel quale con recondite Historie e curiose Eruditioni, il Parlare più antico della Madre de Studi come madre lingua d'Italia (Bologna: Giacomo Monti, 1660).

360 See Diogenes Laertius, Lives of Eminent Philosophers 2.3.8.

361 Thaïs was the hetaera who accompanied Alexander the Great throughout his campaign in Asia Minor, who was also considered responsible for convincing Alexander to burn Persepolis. The hetaerae were mentioned in Terence's The Eunuch, Ovid's Cures for Love, and Cicero's On Friendship, and 
were among the souls in the circle of flatterers encountered by Dante during his journey through Hell (Hell, 18.133-36).

362 This argument is a typical example of the sceptical strategy of arguing with the dogmatist opponent on his own grounds. Since the Sceptic makes no claims of his own, he must adopt the opponent's view for the sake of argument and then show that they lead to contradictories or equipollence.

363 See Plato, Timaeus 73b.

364 See Socrates, 112.

365 The "happy medium" or "golden mean" comes from the vernacular mediocrità (Latin mediocritas), with the well-known meaning of avoidance of extremes of behaviour. See Horace, Odes 2.10.5: "The man who cherishes the golden mean maintains a safe position" (auream quisquis mediocritatem diligit).

366 The reference to the sea as a threatening force of Nature overwhelming humankind and navigation as a metaphor for the uncertainty of human existence recurs throughout Socrates, see also pp. 173, 196-97, 231, 308-309, 310.

367 Virgil, Georgics 2.490, translation slightly modified. The same quotation also occurs in Francis Bacon's Advancement of Learning (book 1, chapter 8,1) by writing that with this verse, "Virgil did excellently and profoundly couple the knowledge of causes and the conquest of all fears together, as concomitantia."

368 See al-Ghazālī, Incoherence of the Philosophers, trans. Michael Marmura (Provo: Brigham Young University Press), 166-77 (seventeenth discussion), where he develops his criticism of the Arabic Aristotelian accounts of causation. One of his main targets was Avicenna's necessitation thesis.

369 On the head of the Olympic Zeus, see Socrates, 57, footnote 117.

370 Luzzatto is referring to Pythagoras's theorem, which demonstrated that it is impossible for the diagonal of a square to be commensurable to its side and thus equal to it. This topic is present in several of Plato's works, such as Laws (819d), Theaetetus, and Meno (82b-85c). A proof of this is briefly mentioned by Aristotle in his Prior Analytics (1.23) and also in a scholium of the last proposition of book 10 of Euclid's Elements based on Aristotle.

371 Luzzatto seems to be referring to the Pythagorean account of harmony, according to which harmony in nature arises from numerical ratios. The Pythagoreans were the first to investigate the concept of musical scales in terms of numerical ratios. Consonance and dissonance were mathematical concepts and the beauty of an interval was dependant on the numbers forming it. See also Socrates 98.

372 The efficient cause is also known as the "moving" cause; see Aristotle, Physics 2.3, and Metaphysics 1.3.

373 Luzzatto seems to be referring to the Aristotelian philosophical tradition.

374 Luzzatto seems to be referring to the nominalists' position towards the problem of universals, which stated that universals were merely names rather than existing realities. According to them, names existed only in the mind; see William of Ockham's Summa of Logic.

375 Luzzatto is paraphrasing a passage of Lucretius's On the Nature of Things before quoting it directly; see Lucretius, On the Nature of Things 4.836.

376 Lucretius, 4.834-35.

377 "Humour" here has the archaic meaning of water or any fluid coming from underground.

378 Luzzatto is probably referring to the Atlantic Ocean.

379 Concerning the transgression and regression of the sea, see also Galileo Galilei, Memorie e lettere inedite finora o disperse (Modena: Vincenzi, 1821), 2:278.

380 Lucan, The Civil War (Pharsalia) 7.449-50 (question mark added).

381 See Socrates, 209-10, footnote 370.

382 Luzzatto is referring to Euclidean geometry, specifically to the triangle postulate; see Euclid, Elements, bk. 1, prop. 32: "In any triangle, if one of the sides is produced, then the exterior angle equals the sum of the two interior and opposite angles, and the sum of the three interior angles of the triangle equals two right angles." 
383 See Socrates, $167-72$.

384 Virgil, Georgics 2.491-92.

385 The defeat of the Athenian army headed by Nicias during the war against Syracuse was attributed to Nicias's superstitious attitude, as he decided to postpone the assault against the enemy because he was afraid of the lunar eclipse. However, he was attacked by the Syracusans and defeated. This episode is related by Thucydides (The History of the Peloponnesian War 7.50.4) and Plutarch (Parallel Lives: Nicias 23.1-6 and 24.1). The same reference also occurs in Luzzatto's Discourse (68v-69r).

386 Theophrastus (ca. 371-ca. 287 BCE) succeeded Aristotle as the head of the Lyceum. Diogenes Laertius provided most of the information about him (see Lives of Eminent Philosophers 5.2.36-50). Theophrastus was the author of many works on different topics, most of them lost. His surviving works testify to his wide-ranging interests, as they extended from ethics, logic, and grammar to biology and physics and strongly impacted Renaissance philosophy and science.

387 See Socrates, 207-14.

388 He is referring to the major term of the syllogism, namely the predicate term of its conclusion.

389 Quintus Remmius Palaemon was a Roman grammarian who lived during the reigns of Tiberius and Claudius. He was the author of Ars, a lost system of grammar which had great success during his lifetime and among later grammarians. Most of the information about him was delivered by Suetonius (see Lives of Grammarians and Rhetoricians 23). He and Aristarchus are frequently cited as the main authorities on grammar.

390 Theophrastus is now referring to the minor term of the syllogism, namely the subject of the conclusion.

391 We have translated the vernacular fermare, from the Latin firmare, as "consolidate."

392 Philolaus was a Pythagorean philosopher who believed that the universe, and thus harmony, resulted from the combination of the limiting and the limitless.

393 As far as Philolaus's book is concerned, Luzzatto's source may be Diogenes Laertius (Lives of Eminent Philosophers 1.5.36-50), who states that Plato bought one of Philolaus's books from his relatives in Sicily, paying forty silver Alexandrian minas. Aulus Gellius (Attic Nights 3.17.1-2) handed down the same episode, although he mentioned a different payment, namely ten thousand dinars.

394 Darics were ancient Persian gold coins, introduced by Darius I by the end of the fourth century CE and also circulating in Greece.

395 Xenocrates (ca. 396/5-314/3 BCE) was a mathematician and philosopher and the third head of the Platonic Academy. In his Metaphysics (8.6.1080b24-37), Aristotle states that among the three principal opinions concerning ideal numbers and their relation to ideas and mathematical numbers, there was that of Xenocrates, who identified ideal numbers with mathematical numbers, showing himself to be close to the Pythagorean doctrine.

396 See Plutarch, Moralia. On the Generation of the Soul in the Timaeus 1012E, Aristotle, On the Soul 1.409b.5-7 and Posterior Analytics 2.4.

397 Luzzatto seems to have in mind the method of ekthesis that Aristotle adopted in the syllogism as he criticises this explanation, because it does not provide a new third term which justifies the inference from a premise to a particular conclusion.

398 The bracchiolum (literally "arm" or "support") was a unit of length mostly used by tailors.

399 Luzzatto is here referring to the distinction between "discrete" and "continuous," where a discrete quantity is a collection of separate and indivisible units and a continuous quantity is instead made up of infinitely divisible units. This was one of the oldest philosophical issues, which had already been debated by the Pythagorean school as well as by Zeno by and Aristotle.

$\mathbf{4 0 0}$ We have translated the original al vivo as "adherence to the truth."

401 The quotation marks were added by the editors and translators.

402 Luzzatto is here referring to one of the most important elements of Aristotelian logic: the concept of definition. According to Aristole (see Posterior Analytics 2 and Topics 6), the definition of a species involves the genus and the differentia, or that part of the definition which is not provided by the genus. 
403 See Aristotle, Physics 2.1.

404 Luzzatto is recalling the Aristotelian definition of motion. See Aristotle, Physics 3.1.201a10-15.

405 See Socrates, 23-32.

406 On the concept of incommensurability, see Socrates, 209-10, footnote 370.

407 On the concept of continuum, see Aristotle, Physics 6.1.231b10-6.2.233b30.

408 See Galileo Galilei, Dialogue concerning the Two Chief World Systems, dialogue 1.

409 Luzzatto means that the triangle becomes three-dimensional by turning in a complete circle.

410 We have translated the vernacular dimenso (Latinism from dimensum) as "measured."

411 Luzzatto seems to be confusing the character from Aesop's fable "The Tortoise and the Hare" and Zeno's second paradox "Achilles and the Tortoise," according to which in a race, the fastest runner can never overtake the slowest. The reason for this, according to Zeno, was that the pursuer must first reach the point whence the pursued started, and therefore the slower will always have the lead (see Aristotle, Physics 6.9.239b5-32).

412 Boethius, The Consolation of Philosophy bk. 5, m. 3, 1-10.

413 Polyphemus was a famous one-eyed giant from Greek mythology. He appears in book 9 of Homer's Odyssey, which narrates the well-known episode of him capturing Odysseus and his men, trapping them in his cave, and the plan Odysseus devises to escape. He makes the giant fall into a drunken sleep and meanwhile hardens a wooden stake in the fire and drives it into Polyphemus's eye. Odysseus and his companions are able to escape from the cave by waiting and hiding themselves underneath the sheep, so when the blind Polyphemus lets his sheep out to graze and touches their backs to be sure that the men are not escaping, he does not perceive them and Odysseus and his men are finally free.

414 Florus, Epitome of Roman History 2.30.29-30.

415 This expression seems to be an abridged paraphrase of a sentence gathered from The Book of Wisdom 6-7 as testified by the later works of Gaetano Felice Verani, Pantheon Argutae Elocutionis et Omnigenae Eruditionis, (Augustae Vindelicorum et Frankfurti: Johannes Caspari Bencard, 1712), 660, where he wrote: quod si viribus, et armis comitantibus audacia, et fortuna plerunque regna parantur; prudential tamen et clementia tutius, quam armis retinentur juxta sapiens monitum Sapien. 6: Si delectamini sedibus, et sceptris, ò Reges populi, diligite sapientiam, seu ut plerique interpretantur, studete clementiae, et prudentiae, ut in perpetuum regnetis (The English translation in the text was made by the editors and translators).

416 Juvenal, Satires 10.365-66.

417 Namely, the distinctive property defining a thing.

418 These sentences seem to recall the Scholastic quidquid conoscitur ad modum conoscentis conoscitur ("a thing known exists in a knower according to the mode of a knower"); see Thomas Aquinas, Summa Theologica 1.1, Q 12, art. 4.

419 We have translated the vernacular indovinare (from the Latin divinare) as "foresee."

420 Translated from the original Greek maxim (Luzzatto uses a Latin translation). This was a very popular maxim in early modern treatises; see Lodovico Zuccolo, Considerationi politiche, e morali sopra cento oracoli d'illustri personaggi antichi (Venice: Marco Ginami, 1621), 43-45. The source of this maxim was probably Diogenes Laertius, Lives of Eminent Philosophers 1.3.70.

421 Suetonius, Lives of the Caesars 2: The Deified Augustus 25.4. Suetonius quoted this saying in Greek as a favourite of Emperor Augustus: speude bradeōs. The same saying is also mentioned by Aulus Gellius (Attic Nights 10.11.5). In his Adages (1001, 2.1.1), Erasmus of Rotterdam debated the value and meaning of this saying by recalling that it was also particularly loved by Vespasian and reporting that the editor and typographer Aldus Manutius had shown him a silver coin, minted during Vespasian's empire, that Pietro Bembo had given him. This coin represented the Roman emperor on one side and a dolphin wound around an anchor on the other. Erasmus explained this image by appealing to Egyptian hieroglyphics, namely that the dolphin, known for its speed, represented haste, while the anchor represented slowness. It is interesting to note that this image, a symbol of prudence, was also reproduced on the frontispiece of Luzzatto's Discourse. 
422 This sentence mirrors the Latin maxim Veritas filia temporis (see Aulus Gellius, Attic Nights 12.11.7), which was taken and transformed into "Time is the father of Truth" by several authors from the Renaissance onwards: see Machiavelli, Discourses on Livy 1.3; Giordano Bruno, La Cena delle Ceneri (The Ash Wednesday Supper). This maxim also became the Academic “endeavour” (impresa) of the Venetian editor Francesco Marcolini.

423 Luzzatto is perhaps speaking metaphorically here of Venice in the face of the conquests of the Ottoman Empire; see Socrates, footnote 2.

424 On the formalists, see Socrates, 153, footnote 307.

425 Literally "the centre around which all his thoughts revolve."

426 On formality, see Socrates, 239, footnote 417.

427 Thrasymachus was a sophist from Chalcedon praised for his skill as a rhetorician by Plato in Phaedrus 266c.

428 The same metaphor occurs in Galileo, Sidereal Messenger, 62, and it had been already mentioned by Luzzatto in his Discourse (7v).

429 On the fictitious letter written by Reason to denounce the usurpation of Authority, see Socrates, $5-8$.

430 This reference to Plato's Phaedrus has already occurred in Socrates, 100.

431 The Delphic maxim was inscribed in the entrance to the temple at Delphi, according to Pausanias's Description of Greece 10.14.1-2. It was later adopted by Socrates.

432 An almud (Lat. Modius) is an obsolete unit of measurement.

433 Luzzatto is referring to the adage quoted by Cicero (Laelius On Friendship 19.67-68): "Men must eat many a peck of salt together before the claims of friendship are fulfilled" (Multos modios salis simul edendos esse, ut amicitiae munus expletum sit); originally from Aristotle, Nicomachean Ethics 8.3. 434 Luzzatto is here recalling the maxim in media stat virtus, namely that virtue stands in the middle between extremes (see mainly Aristotle, Nicomachean Ethics 2.6). See also "happy medium" (or mediocritas) in Socrates, 205 footnote 365.

435 On friendship, see Luzzatto, Discourse, 46v.

436 The sentence Luzzatto quotes is mentioned verbatim by the Spanish diplomat Diego de Saavedra Fajardo (1584-1648) in his anti-Machiavellian book L'idea di un prencipe politico Christiano rappresentata con bellissime imprese, quali dimostrano il vero esser politico, con esempi historici, e discorsi morali. Dall' ultima, e più copiosa editione, hora trasportata dalla lingua spagnuola, dal signor dottor Paris Cerchieri (Venice: Marco Garzoni, 1648), 511. The sentence is a paraphrase of Tacitus's nec ausus est satis nec providit (Histories 3.40), translated in the text.

437 See Thomas Aquinas, Commentary on Aristotle’s Physics, book 8, lect. 2, n. 976.

438 That is, mercury.

439 Haruspices practised a form of divination called haruspicy, consisting of the reading of omens from the entrails of sacrificial animals.

440 Augurs were Italic and Roman priests who practised augury, namely predicting the positive or negative outcomes of any undertaking by interpreting natural events.

441 Auspices interpreted the will of the gods by observing the flight of birds.

442 Judicial astrologists forecasted the future by observing and interpreting the movements of the heavenly bodies.

443 "Mathematician" was an ancient term with the meaning of "magician, astrologist, clairvoyant." 444 Geomantics predicted the future by interpreting markings on the ground or the patterns formed by thrown handfuls of sand, soil, or rocks.

445 Hydromantics practised a form of divination called hydromancy, made by means of water.

446 Calchas was the famous seer of Argus who received his gift from Apollo; in the Iliad, Homer praised him as the best augur there had ever been. He played a crucial role during the Trojan War by predicting the fall of Troy in the tenth year of the war. 
447 Luzzatto's quotation corresponds to the Latin translation of Homer's Iliad made by Helius Eobanus Hessus, Poetarum omnium seculorum longe principis homeri Ilias (Paris: 1545), book 1, 8v. The English translation provided here is from the Loeb edition.

448 This paragraph recalls an important element of classical sceptical thought; namely, it provides an excellent description of the mental unhappiness and anxiety from which, according to the Sceptics, epoche (suspension of judgment) is meant to free one, inducing ataraxia (state of tranquillity and freedom from worry and distress).

449 Juvenal, Satires 10.22.

450 The metaphor of the "naked Truth" (nuda veritas) has been a topos from Horace (see Odes 1.24.6) onwards. It is meant to underline Truth's original simplicity and directness and how its display was troublesome for common people to understand as they were used to relying on embellished forms of it. This topic also occurs in Luzzatto's Discourse (3r-v), see Veltri, Alienated Wisdom, 231-33.

451 Ovid, Metamorphoses 1.84-86. The same quotation also occurs in Montaigne's Essays (2:12, 509). 452 Lucretius, On the Nature of Things 5.837-39.

453 Lucretius, 5.855-56.

454 Luzzatto seems to be referring here to the fair reason of state, which was respectful of God's laws and morality, advocated by Giovanni Botero in his treatise The Reason of State against the unfair, atheistic, and merely utilitarian reason of state promoted by Tacitus and Machiavelli. See Botero, Della ragion di stato (Venice: Appresso I Gioliti, 1589). See also Martino Manfredi, Manuale politico e morale ossia repertorio alfabetico di aforismi e concetti sententiosi politici, morali e sacri fra I più praticabili, $e$ direttivi dell'huomo Civile e Christiano (Genova: Antonio Giorgio Franchelli, 1682), 394. As an example of mismanagement of the state's policy, see Traiano Boccalini, De' Ragguagli di Parnaso I (Milan: Gio. Battista Bidelli, 1615), 350. For a recent study on Luzzatto's political thought, see Vasileios Syros, "Simone Luzzatto's Image of the Ideal Prince and the Italian Tradition of Reason of State," Redescriptions: Yearbook of Political Thought and Conceptual History 9 (2005): 157-82.

455 The equant (punctum aequans), introduced by Ptolemy in book 5 of his Almagest, was a hypothetical point adopted to describe the speed of a planetary orbit.

456 Hippocrates, Aphorisms 1.3. This translation is from the original Greek. Luzzatto may also have read Joseph Delmedigo's Hebrew translation of Hippocrates's Aphorisms, which was probably printed in 1650; a considerable sample of his translation and commentary may be found in his Sefer Elim (109-16). See Issachar Teller, Be'er Mayim Hayyim with Hippocrates's Aphorisms translated into Hebrew by Joseph Solomon Delmedigo, [in Hebrew,] ed. Joshua Leibowitz (Jerusalem, 1968); Isaac Barzilay, Joseph Shlomo Delmedigo (Yashar of Candia): His Life, Works and Times (Leiden: Brill, 1974), 127.

457 In the original copy of Socrates, this page was incorrectly numbered 258; this has been corrected to 264 .

458 A similar reference to the impact of apparent and less important things on the spread of knowledge rather than their essentiality appeared in Luzzatto's Discourse (75r) and is grounded in Francis Bacon's criticism of human learning (The New Organon, 8).

459 The vernacular animo has been translated as "soul" here due to the psychological framework in which Luzzatto's argument is developed in this passage.

460 Lucan, The Civil War (Pharsalia) 1.181-82. The same verses were already quoted by Luzzatto in his Discourse (41v). Verse 181 was also quoted by Francis Bacon in his Essays 15.45.

461 Tacitus, Agricola 3.1.

462 The application of the doctrine of antiperistasis to virtues and vices is also repeated on page 282 . Luzzatto had already appealed to this doctrine in his Discourse (55v) in order to explain how people react in the face of a threat from an enemy, as well as how different religious groups react when living together in the same society; see Veltri, "Economic and Social Arguments."

463 The last two quotations are presumably paraphrases of Tacitus, Annals 1.2. The English translations were made by the editors and translators. 
464 Aconitum and napellus were described in the past as two different poisonous plants, often used throughout history for making poisons; see Umberto Quattrocchi, World Dictionary of Medicinal and Poisonous Plants (Boca Raton, FL: CRC Press, 2012).

465 Literally "the moon swoons." Luzzatto is playing with the Italian words svanire (to disappear) and svenire (to swoon).

466 Tasso, The Liberation of Jerusalem, 15.20.3, 5. The quotation is lacking the fourth verse: Copre $i$ fasti e le pompe arena ed erba ("Its pomp and glory lost in scrub and sand").

467 A contrary argument is mentioned on page 127 in the discussion of the topic of memory.

468 The reference to the small grains of sand is debated by Archimedes's The Sand Reckoner, where he set out to define an upper limit for the number of grains of sand which would fit into the universe. The same expression also occurs in Galileo Galilei's Dialogue concerning the New Science (1638), First day.

469 This argument based on the metaphor of men/ants may have been inspired by Francis Bacon, who wrote in his Advancement of Learning, book 1, chapter 8, 1: "So certainly, if a man meditate much upon the universal frame of nature, the earth with men upon it (the divines of souls except) will not seem much other than an ant-hill, whereas some ants carry corn, and some carry their young, and some go empty, and all to and fro a little heap of dust."

470 Lucan, The Civil War (Pharsalia) 2.381-83.

471 This way of life Luzzatto describes here, based on following Nature, using restraint or moderation and respecting the social and political laws, seems to recall Sextus Empiricus's rules for how the Sceptic ought to live his life; see Outlines of Scepticism 1.237: "we said above that ordinary life, which the Sceptics too participate in, is fourfold, consisting in guidance by nature, necessitation by feelings, handing down of laws and customs, and teaching of kinds of expertise."

472 A similar argument also occurs in Luzzatto's Discourse, 18r.

473 On the topic of “true religion," also occurring in Luzzatto's Discourse, 67v, see Guido Bartolucci, Vera religio: Marsilio Ficino e la tradizione ebraica (Turin: Paideia, 2017); Veltri, Alienated Wisdom.

474 Luzzatto may be alluding to Matthew 13:24. In ancient texts, weeds were considered to be corrupt seeds. On this topic in rabbinic literature, see Bereshit Rabbah 28:8. See Kommentar zum Neuen Testament aus Talmud und Midrasch, ed. Hermann L. Strack and Paul Billerbeck, 4th ed. (München: Beck, 1965), 1:667.

475 A reference to homo homini lupus has already occurred in Socrates, 167, footnote 323.

476 This expression seems to recall sensus divinitatis ("sense of deity"), used by the Protestant Reformer John Calvin at the beginning of his Institutes of Christian Religion, trans. Henry Beveridge (Grand Rapids, MI: Christian Classics Ethereal Library, 1845) chapter 3, 1. By this term, he meant that there is a sense that exists in the human mind as a natural instinct which provides human beings with the knowledge of God.

477 The power of fascination as a source of superstitious beliefs also occurs in Socrates, 290. See also Francis Bacon, Advancement of Learning, chapter 11, 3.

478 Deucalion was the son of Prometheus. He was informed by his father of Zeus's anger and his plan to end humanity in the Bronze Age. According to Ovid's Metamorphoses - Luzzatto's source here as is evident from the quotation - when Zeus unleashed a deluge, dramatically described by the poet as being intended to punish humanity's moral and religious corruption, Deucalion and his wife were rescued from the flood by building a chest. They landed on Mount Parnassus, where Zeus decided to grant their request to repopulate the earth. According to the myth, they threw rocks behind themselves and the stones formed people.

479 Ovid, Metamorphoses 1.129-31.

480 Draco (ca. seventh century BCE) was the first legislator of Athens; the laws he established were remembered for their harshness.

481 See Socrates, 63. 
482 On the meaning of the tortoise and the snail from the Middle Ages onwards, see Socrates, 63, footnote 125 .

483 Virgil, Aeneid 6.258.

484 Theriac is a concoction made from opium, used since antiquity for medical treatment and known for its analgesic effects, but potentially also a poison in the wrong dose. Thanks to Venice's primacy in this type of trade, the apothecaries (speziali) of Venice became well-known for the production of medical cures based on opium, but also for their dangerous experimentations and misuse of this substance. On this topic, see Andrea Mozzato, "Oppio, triaca e alter spezie officinali a Venezia nella seconda metà del Quattrocento," in Venice and the Veneto during the Renaissance, ed. Michael Knapton, John E. Law, and Alison A. Smith (Florence: Firenze University Press, 2014), 155-84.

485 The same criticism of human impertinence in claiming to know heaven while remaining ignorant of their lives on earth occurs in Montaigne; see Essays, 2:12, 564: "I have always felt grateful to that girl from Miletus who, seeing the local philosopher Thales with his eyes staring upwards, constantly occupied in contemplating the vault of heaven, made him trip over, to warn him that it was time enough to occupy his thoughts with things above the clouds when he had accounted for everything lying before his feet. It was certainly good advice she gave him, to study himself rather than the sky; for, as Democritus says through the mouth of Cicero, 'Quod est ante pedes, nemo spectat: coeli scrutantur plagas' [Nobody examines what is before his feet: they scrutinize the tracts of the heavens]."

486 Aristotle was the author of this statement (see Generation of Animals 2.738b110-35), which occurred as a pattern in treatises up until the nineteenth century.

487 On the concept of the "citizen of the universe," see Socrates, 15, footnote 36.

488 See Socrates, 271-72.

489 Lucan, The Civil War (Pharsalia) 2.383.

490 On antiperistasis, see Socrates, 267, footnote 462.

491 Xerxes, known as “The Great," the son of Darius I, was the fourth king of Persia, who extended his empire at its territorial apex. After the defeat of his father's army during the first Greco-Persian War, he started a new campaign, the second Greco-Persian War, for the occupation of Greece (480-479 BCE), which also ended in the defeat and withdrawal of the Persian forces.

492 This sentence paraphrases a famous passage of Valerius Maximus's Memorable Deeds and Sayings 8.6.2, where it was supposedly said by Alexander the Great and not Xerxes: "Alexander's appetite for fame was insatiable. He said to his companion Anaxarchus, who was retailing on the authority of his teacher Democritus the existence of innumerable worlds: 'Alas for me, I have not yet made myself master of one!”’

493 This statement may be found in Traiano Boccalini, Ragguagli di Parnaso Centuria Primo (Venetia: Pietro Ferri, 1612), 89:4, where Machiavelli himself claims that his opponents have called him an author of "angry and desperate politics" (arrabbiata e disperata politica).

494 Tacitus, Annals 15.1.4.

495 Tacitus, 15.1.4. This quotation, together with the previous one from Tacitus, was commonly mentioned in early modern times to describe the unfair, atheistic, and merely utilitarian reason of state described by Tacitus and Machiavelli. On this topic, see Socrates, 260, footnote 454.

496 Luzzatto is referring to a lunar eclipse.

497 Virgil, Aeneid 3.56-57.

498 Maimonides uses the image of matter being likened to a harlot, based on Proverbs 6:26, in The Guide of the Perplexed, trans. Shlomo Pines (Chicago: University of Chicago Press, 1963), vol. 1, introduction, 13-14 and vol. 2, part 3, 8, 431. See Josef Stern, The Matter and Form of Maimonides' Guide (Cambridge: Harvard University Press, 2013), 357-58. Judah Leon Abravanel (Leone Ebreo), in his Dialogues of Love (1535), also refers to this interpretation of matter. See Dialogues of Love, trans. Damian Bacich and Rossella Pescatori (Toronto: University of Toronto Press, 2009), 88. The same metaphor also occurs in Alessandro Piccolomini's Filosofia naturale (1585), in which he called it publichissima meretrice; see Filosofia naturale (Venetia: Francesco de' Franceschi Senese, 1585), vol. 1, bk. 3, 14). 
499 The same examples also occurred in Luzzatto's Discourse, 60r, and are gathered from Sextus Empiricus, Outlines of Scepticism 3.205.

500 See Plato, Republic 5.464b-e, where Socrates discusses the requirement that all wives and children must be held in common.

501 See Diogenes Laertius, Lives of Eminent Philosophers 6.2.

502 Luzzatto's metaphor recalls Sextus Empiricus, Outlines of Scepticism 1.206: "In the case of all the sceptical phrases, you should understand that we do not affirm definitely that they are true - after all, we say that they can be destroyed by themselves, being cancelled along with what they are applied to, just as purgative drugs do not merely drain the humours from the body but drive themselves out too along with the humours." Also 2.188: "Arguments, like purgative drugs which evacuate themselves along with the matters present in the body, can actually cancel themselves along with the other arguments which are said to be probative." See also Socrates, 62.

503 Galen, influenced by Hippocrates's theory of humours, stated that "the opposite is cured with the opposite"; see Galen, Method of Medicine 8.2.535K.

504 Paracelsus stated, in direct opposition to the Galenic medical tradition, that "like cured like"; see Lawrence I. Conrad, Michael Neve, Vivian Nutton, Roy Porter, and Andrew Wear, The Western Medical Tradition: 800 BC to AD 1800 (Cambridge: Cambridge University Press, 1995), 315.

505 This saying may be ascribed to Cicero, who wrote that only a new love could dispel the melancholy of an old one "as one nail can be driven out by another" (clavo clavum eiiciendum); see Tusculan Disputations 4.74-75. A similar version of this saying was debated by Erasmus of Rotterdam, quoting Cicero in his Adages 104.1.2.4.

506 Horace, Satires 1.1.106-7.

507 Luzzatto is referring to the ring of Gyges, the legend of which is mentioned by Plato in his Republic (10.612b) during Glaucon's speech: according to the myth, the ring provided its owner with the power to become invisible. The meaning of this story was that moral actions are possible as long as there are rules capable of punishing injustices. The topic occurs also in Boccaccio's Decameron (3rd day, 1.3).

508 On the power of fascination, see Socrates, 276, footnote 477.

509 Outer fortification.

510 Cyrus's pedagogue was Xenophon of Athens, the author of the Cyropaedia, the first book of which in particular is focused on the education of the ideal ruler.

511 A similar argument debating the issue of false judgment is discussed in Socrates, 203.

512 On the distinction between preventive and curative medicine and the Jews' preference for the former, see Martin P. Golding, "Preventive vs. Curative Medicine: Perspectives of the Jewish Legal Tradition," Journal of Medicine and Philosophy 8, no. 3 (August 1983): 269-86.

513 Cicero, On Duties 1.33.

514 The wise men to whom Luzzatto is now referring are the ancient Stoics, whose ethics taught freedom from passions and thus from every external event affecting us through pursuing apatheia, namely a state of peace of mind achieved by regarding many things as indifferent. The Stoic philosophy believed in constant spiritual practice, such as daily self-reflexion, and contemplation of death, as Luzzatto himself recalls. The perfection of one's rational nature is the condition of being virtuous, and "good" lies in exercising this alone. See John Sellars, ed., The Routledge Handbook of the Stoic Tradition (London: Routledge, 2016), and Cicero, Tusculan Disputations 3-4, where he discusses the possibility and desirability of Stoic apathy.

515 From the vernacular havendo sempre in bocca, a translation of the Latin proverb in ore habere.

516 Horace, Epistles 1.6.1-2.

517 Luzzatto is here recalling a story told by Pliny (Natural History 7.38), in which the subject is not Apelles's painting, but rather Protogenes's most famous work, a portrait of Ialysus, son of Helios and legendary founder of Rhodes. According to Plutarch (Parallel Lives: Demetrius 22.7), the painting took seven years to complete and was greatly admired by his competitor Apelles. Demetrius I Poliorcetes besieged the city and confiscated the portrait in his siege of Rhodes in 305-304 BCE. According to 
Pliny, an embassy was sent to beg him not to destroy the famous painting and Demetrius, although he was determined to punish the town for its support of his rival Ptolemy I, nevertheless declared that he would rather burn a picture of his own father than this precious work. Pliny recalls that Demetrius spared Rhodes itself to avoid the risk of harm to the portrait.

518 Tacitus, Annals 4.38.5, slightly modified.

519 Luzzatto's quotation seems to have been taken from Marsilio Ficino, Platonis Atheniensis, Philosophi summi ac penitus divini opera, quae ad nos extant omnia, per Ianum Cornarium Medicum Phisicum latina lingua conscripta (Basilea: Froben, 1561): "Phaedo," 38: ut intemperantia quadam temperantes sint. The English translation was made by the editors and translators.

520 See Homer, Odyssey 12.39-46.

521 Euripides, quoted in Aristotle, Nicomachean Ethics 8.1.1155b3-4, slighty modified from the Loeb edition.

522 Contrary to Socrates's speech in Plato's Symposium (199d-204c), which describes love as the son of contrivance and poverty, Luzzatto presents it as having been descended from plenty (copia) and poverty. The same variation may be found in Marsilio Ficino, Commentary on Plato's Symposium, trans. Sears Jayne (Dallas: Spring Publications, 1985), 6.10.

523 Damon and Pythias were two followers of the Pythagorean school of philosophy, who became legendary throughout history for their truthful and reliable friendship, as Luzzatto states; see Cicero, On Duties 3.45.

524 On the formalists, see Socrates, 153, footnote 307.

525 Isocrates (436-338 BCE) was the most famous Greek rhetorician of his time; his teachers were Gorgias and Prodicus and he was acquainted with Socrates. In 392-390 BCE, he found the first academy of rhetoric.

526 Tacitus, Annals 14.44.4.

527 Luzzatto seems to be recalling the hedonism of Aristippus of Cyrene; see Aelian, Historical Miscellany 14.6.

528 This is a reference to Stoic equanimity or apatheia, namely a state of mind free from passions.

529 Luzzatto seems here to be recalling Epicurean ascetism.

530 This was the Stoic position.

531 This is a reference to one of the famous phrases carved in the entrance of the Delphic temple of Apollo, "know thyself," which was the maxim at the origin of Socrates's inquiry to show the limits of human understanding; see Xenophon, Memorabilia 4.2.24 and many of Plato's dialogues.

532 This is another main principle of Stoicism.

533 Luzzatto seems to have in mind the Aristotelian concept of habitus; see Nicomachean Ethics 2.5. See also Socrates, 131; 147; 249-50.

534 This is probably a reference to Milo of Croton and the other athletes; see Francesco Zorzi, L'armonia del mondo, ed. and trans. Saverio Campanini (Milano: Bompiani, 2010), 187.

535 This is a reference to the famous statement Orandum est ut sit mens sana in corpore sano ("You should pray for a healthy mind in a healthy body") from Juvenal, Satires 10.356. See also Zorzi, L'armonia del mondo, 187.

536 Luzzatto seems to be recalling those who followed the statement carpe diem, quam minimum credula postero ("Pluck the day, trusting as little as possible in tomorrow") from Horace, Odes 1.11.

537 Luzzatto is recalling ancient Scepticism here, which set no final goal and taught respect for the common laws of the society where one lives; see Sextus Empiricus, Outlines of Scepticism 1.16; Montaigne, Essays 2:8, 419.

538 We have translated the vernacular convenevolezza, corresponding to "convenience" in the obsolete sense of "aptitude, fitness," as "fittingness."

539 The source of the idea of the "philosopher king" is Plato, Republic 5.473d-e. Concerning the Jewish tradition of this topic, see Abraham Melamed, The Philosopher-King in Medieval and Renaissance Jewish Political Thought (Albany, NY: State University of New York Press, 2003). 
540 "Scruple" is here used in the old sense of "a small unit of weight."

541 This repeats the criticism of the legendary "Golden Age" which also occurred in Socrates, 78, see footnote 153.

542 On magnets, see Socrates, 71-72, footnote 143.

543 Luzzatto is referring to the regular (isochronous) motion of pendulums, the first investigation into which was made by Galileo in 1602. In 1641, Galileo conceived and designed a pendulum clock, which his son began to construct, but did not complete before his death. The first pendulum clock was built in 1658 by the Dutch scientist Christian Huygens. See Abbott Payson Usher, A History of Mechanical Inventions (New York: McGraw-Hill, 1929; repr. New York: Dover Publication, 1988), 310-21.

544 The Greek term philautia, "self-love," appears in Aristotle's Nicomachean Ethics 9.8. Aristotle distinguishes two senses of self-love: one is morally commendable, as a good person must be a self-lover in order to wish for the noblest good and also make others benefit from it. The other sense of philautia is pejorative, as it must be identified with selfishness or egoism. Cicero uses the expression communis philautia to address the self-centredness and vanity of authors (see Letters to Atticus 13.13.1). Erasmus of Rotterdam introduces philautia in his Praise of Folly as an indispensable servant of folly.

545 Ovid, Art of Love 3.397.

546 The translation of the vernacular animo as "soul" instead of "mind" is due to the context, which clearly refers to the relationship between the soul and the body in which the latter is conceived as a prison or dwelling of the former.

547 Ecclesiastes 7:29. Luzzatto is translating from the Hebrew: לבד ראה זה מצאתי אשר עשה האלהים את האדם ישר והנה בקשו חשבנות רבים The Clementine Vulgate version is fecerit Deus hominem rectum, et ipse se infinitis miscuerit quæstionibus.

548 This is a reference to Socrates, 138.

549 Lucretius, On the Nature of Things 2.1-2. In this passage, Lucretius described the serene sanctuaries of philosophy.

550 Lucan, The Civil War (Pharsalia) 9.573-77.

551 While in his Discourse 30r Luzzatto stated that he was willing to follow the probable or what was resembling the truth (verisimile) like a new Academician. In this passage of Socrates, Luzzatto also puts what resembles the truth into doubt.

552 On the idea of religion which distinguishes human beings from animals more than reason itself does, see Marsilio Ficino, De Christiana religione (Florence: Nicolò di Lorenzo, 1476), 1.33-34 and Marsilio Ficino, Platonic Theology, trans. Michael J. B. Allen, ed. James Hankins (Cambridge, MA: Harvard University Press, 2004), 4:291-99 (14.9).

553 Behind this concept of the homeland's rites and religions, Luzzatto may be referring to Eusebius of Caesarea's idea of three religions: the poetic, the philosophical, and the civil (see Eusebius, Preparation for the Gospel, 4.1.130). Luzzatto was familiar with Eusebius's work and mentioned it in his Discourse, 73v. 